\title{
Tratamiento televisivo de la información de sucesos. Análisis periodístico de los programas La Mañana, El Programa de Ana Rosa y Espejo Público
}

\author{
Treatment of crime and events information on TV shows. Journalistic \\ analysis of "La Mañana", "El Programa de Ana Rosa" and "Espejo Público"
}

\author{
Dra. Rosa Rodríguez Cárcela \\ Universidad de Sevilla | Calle Américo Vespucio, 27, 41092 Sevilla | España | \\ https://orcid.org/0000-0003-1718-7564 | rmaria.rodriguez@juntadeandalucia.es
}

Fechas | Recepción: 12/06/2021 | Aceptación: 09/09/2021

\begin{abstract}
Resumen
Este trabajo de investigación realiza un análisis periodístico sobre el tratamiento televisivo de la información de sucesos en los programas La Mañana (TVE), El Programa de Ana Rosa (Telecinco) y Espejo Público (Antena 3). El estudio se centra en la descripción de diversas variables, tomando como referencia el visionado de emisiones televisivas de 2018. Cada uno de los magacines analizados tienen tratamientos diferenciados que marcan sus estilos informativos, aunque el esquema de formato televisivo sea muy similar, con conexiones en directo y el recurso abusivo de las tertulias. Se han estudiado preferentemente las noticias de sucesos, aunque también se incluyen informaciones de tribunales con temática de sucesos. Los resultados ponen de manifiesto que estos contenidos temáticos tienen gran importancia en los tres matinales, especialmente en la cadena pública, ya que en las privadas las informaciones sobre política y corazón adquieren cada vez mayor protagonismo en sus programaciones.
\end{abstract}

Palabras clave: información sucesos, programas televisión.

\begin{abstract}
This research paper carries out a journalistic analysis about the treatment of the news of crime and events on TV shows La Mañana (TVE), El Programa de Ana Rosa (Telecinco) and Espejo Público (Antena 3). The study focuses on the description of various aspects of such informations on the broadcasts of those TV shows during 2018. Each of the shows analyzed offers diverses treatments that define their informative style, although the scheme of all of them is very similar, including live connections and abuse of talk shows. The news of crime and events have been studied preferably, including also the court informations. The results indicate that these matters have a great relevance in the three morning TV shows, especially in the public $T V$ one, since in the private TV shows the informations on politics and gossip are gaining more and more prominence in their contents.
\end{abstract}

Keywords: news of crime and events, TV
shows. 


\section{INTRODUCCIÓN}

En este estudio partimos de la base de que la televisión -a diferencia de la prensa y salvando los servicios informativos y telediarios-, es ante todo un medio de entretenimiento. En los tres programas televisivos analizados la noticia de sucesos se convierte en espectáculo para ganar audiencia y conseguir una información de impacto para los telespectadores. La Mañana, EI Programa de Ana Rosa y Espejo Público emiten en formatos muy parecidos y, por tanto, comparables: magacines matinales en directo, de lunes a viernes, conducidos por presentadoras estrellas (todas ellas periodistas y mujeres), donde se informa, debate y comenta la actualidad diaria con tertulianos y las informaciones de sucesos adquieren un protagonismo destacado.

\section{METOdOLOGÍA}

La metodología empleada ha utilizado como fuente base el análisis descriptivo de las seis emisiones televisivas correspondientes a los días 3 y 4 de octubre de 2018, de los programas Las Mañanas de RTVE (temporada 9a), El programa de Ana Rosa de Telecinco-Mediaset España (15a temporada) y Espejo Público de Antena3-Atresmedia (13a temporada). En total se han contabilizado 111 registros (contenidos informativos), de los cuales se han estudiado de forma más detallada 26 noticias de sucesos y otras 17 de tribunales con temática de sucesos. En conjunto 43 informaciones representativas del tratamiento televisivo. Este material audiovisual ha sido visualizado desde las páginas web de los citados espacios donde se encuentran almacenados los archivos que ya han salido al aire. Hay que aclarar que el tiempo de emisión es menor duración que el que se visualiza en televisión, ya que la publicidad es más corta. En este sentido, se han visualizado unas 15 horas entre los tres programas.

Las variables periodísticas analizadas para elaborar este estudio son las siguientes: número total de noticias (contenidos o registros informativos), temática, titulares, fuentes, géneros, tiempo y tratamiento. El análisis de estas características, tanto cualitativas como cualitativas, también muestra los formatos audiovisuales que complementan la información de sucesos.

La elección de dichos magacines matutinos con más audiencia de la televisión en España nos ofrece una muestra representativa de modelos televisivos en teoría diferentes -dos privados y uno público-, pero con formatos y contenidos similares donde las noticias de sucesos y tribunales/sucesos ocupan relevancia informativa y son objeto de debate. Hemos acotado el análisis al seguimiento de tres espacios importantes en sus parrillas de programación y, por tanto, son un reflejo aproximativo del tratamiento del periodismo de sucesos en el medio televisivo. El programa de Ana Rosa es el que tiene mayor audiencia por las mañanas en la televisión española, seguido de Espejo Público y en tercer lugar La Mañana.

Junto a los datos resultantes tras el análisis del visionado de los tres programas, se incluyen imágenes capturadas de cada uno de los magacines que sirven para ilustrar los datos que se describen, así como un gráfico y siete tablas en el apartado final de las conclusiones.

\section{LA MAÑANA}

Magacín de La 1 de Televisión Española que se emite en directo de lunes a viernes, de 10:00 a 12:00 horas, y presentado en 2018 por la periodista María Casado junto a un copresentador. A diferencia de los otros dos programas, La Mañana tiene menor duración, ya que el contenido 
de actualidad política y debate se emiten previamente en otros espacios matutinos ${ }^{1}$ Por tanto, se trata de un programa más centrado en noticias de sucesos y sociedad. Según recoge la web de RTVE, este programa hace una apuesta reforzada por "la actualidad, más cerca de la calle" y aclara que tiene un carácter eminentemente informativo, centrándose en la actualidad y en las noticias que "interesan y afectan a los ciudadanos en su vida cotidiana". Señala que en su ideario son muy importantes los contenidos sociales para reflejar "la realidad de nuestro país", incidiendo en que TVE es una cadena pública y que su información debe regirse -como especifica su Estatuto de Redacción- por "el rigor, la independencia, neutralidad y objetividad". Por los datos analizados y las visualizaciones efectuadas afirmamos que dicha actualidad se refiere mayoritariamente a los sucesos.

\section{Día 3 octubre}

Número total de noticias/contenidos informativos:

Del total de los 15 registros informativos computados, 6 son de sucesos (supone que cerca de la mitad de sus contenidos, un 35,29\%, están centrados en los sucesos) y 3 de tribunales sobre temáticas de sucesos (un 23,52 \%). Por tanto, un elevado porcentaje de sus contenidos cercano al $60 \%$ (un 58,82 \%) están dedicados a esta temática. Las restantes informaciones son las siguientes: 2 de cultura/espectáculos, 2 de sociedad, 1 de política y 1 de Operación Triunfo (autopromoción).

\section{Temática:}

Las seis noticias de sucesos registradas son un tiroteo en Estepona, el desalojo de un poblado chabolista por narcotráfico en Palma, abusos laborales y sexuales en Huelva, acoso escolar en España, agresiones a un profesor en Sagunto e insultos de dos cantantes a una concejala en Órgiva. Los tres casos judiciales son los de 'Nadia', 'Juana Rivas' y 'Crimen Susqueda'. La mayoría pertenecen al ámbito delictivo.

\section{Titulares:}

Las seis noticias de sucesos se encabezan con los siguientes titulares: "Tiroteo en plena calle. Se llevan a punta de pistola a un hombre y huyen", "Desalojan Son Banya. Los vecinos se manifiestan para evitar el derribo de las chabolas", "Trabajadoras de Huelva denuncian abusos laborales y sexuales", "Agresión a un profesor. El padre de una niña de 9 años pega un cabezazo a un maestro", "Un caso de acoso escolar al día" y "Concierto de Andy y Lucas. Se les acusa de insultar a una concejala ante 2.000 personas". Prevalecen los títulos informativos, aunque algunos de los empleados pueden incurrir en el alarmismo (Ej.: "El miedo se apodera de Estepona"), recurriendo al sensacionalismo.

\section{Fuentes:}

Las fuentes sobre el tiroteo (la Policía Nacional y los vídeos colgados en redes sociales por los testigos), el conflicto de Son Banya (los vecinos afectados y las municipales) y la agresión a un profesor (las versiones de la propia víctima y del director del colegio) se cubren con los datos

1 En septiembre de 2020 este programa se reconvierte en La Hora de La 1, también un magacín de actualidad, pero de mayor duración (de 8 a 13:00 horas), donde se incorporan contenidos de política. La nueva presentadora es Mónica López, que no es periodista y anteriormente se encargaba de la información meteorológica. López es cesada por TVE y en la nueva temporada, iniciada en septiembre de 2021, los presentadores son los periodistas Marcos Sala y Silvia Intxaurrondo. 
recabados por los reporteros que acuden al lugar de los hechos, complementados con las imágenes en directo tomadas por las cámaras de TVE. La relativas al acoso escolar y a los insultos a una política en Órgiva se nutren con entrevistas a las víctimas por parte de la presentadora (una en el plató y otra telefónica) y la de los abusos sexuales y laborales suponemos que es de agencia porque no se citan fuentes (fuente indeterminada sin atribución).

Prevalecen las fuentes informativas no oficiales (16) frente a las institucionales u oficiales (4). A ellas hay que añadir las fuentes indeterminadas; es decir, las que no constan o no se citan directamente (3). Dentro de las no oficiales, las más citadas son las que provienen de las víctimas, los testigos y las vecinales, así como los datos recabados de la observación directa de los reporteros de calle. Las oficiales más habituales son las policiales, municipales y de centros educativos. A estas fuentes informativas se unen las imágenes emitidas, la mayoría en directo y propias de TVE y otras minoritarias recogidas de vídeos publicados en redes sociales. Todo ello se complementa con las valoraciones y aportaciones de los tertulianos, de los cuales la mayoría no son especialistas en la materia.

\section{Géneros:}

Es un programa muy dinámico. Del conjunto de los 15 registros informativos computados, en 11 se utiliza la noticia como entradilla informativa en el plató y el posterior desarrollo de los hechos informativos con la narración de los reporteros de la calle. En menor medida se emplean breves reportajes en off realizados en la redacción y la más minoritaria es la entrevista en el plató a los protagonistas de los hechos.

\section{Tiempo:}

Se recogen los minutos aproximados que se le dedican a cada uno de los sucesos emitidos. El inicio o arranque del programa -que incluye la portada con el enunciado de los contenidos informativos y la emisión de las imágenes alusivas a los mismos y de los invitados a la tertulia-, dura unos 2 minutos. Al tiroteo en Estepona se le dedican 8 minutos, a Son Banya 11', la agresión a un profesor en Sagunto 7', al tema de acoso escolar 13', los insultos en un concierto en Órgiva 3' y los abusos laborales y estafa a temporeras 2'. Unos 44 minutos aproximadamente $(42,30 \%)$, de los cuales se equilibra el tiempo dedicado a información y el de opinión y análisis en la mesa de debate. Los juicios sobre los casos 'Nadia' (el de más emisión), 'Juana Rivas' y 'Crimen Susqueda' (ambos con tiempos similares) ocupan unos 21 minutos aproximadamente $(20,19 \%)$, en los que hay más tiempo dedicado a opinión que a información.

En total, sucesos y tribunales ocupan 1 hora y 5 minutos y el programa dura 1 hora y 44 minutos. Por tanto, del total de los 104 minutos de duración un 62,5 \% del tiempo está dedicado a estos contenidos con temática de sucesos.

\section{Tratamiento:}

El programa arranca con los titulares de tres noticias de portada: un tiroteo en Estepona, el juicio 'Caso Nadia' en Lérida y el desalojo vecinal de un poblado chabolista en Palma por narcotráfico. A continuación, la presentadora conecta en directo con las imágenes de los tres reporteros con micrófono en mano en los lugares de los hechos y se emite a pantalla completa. Después aparece la imagen en el plató del copresentador que anuncia el resto de las 
noticias que integrarán el programa, la mayoría de sucesos. Posteriormente, María Casado muestra una imagen genérica de los invitados que componen la denominada 'Mesa de debate', dedicada al análisis y la opinión de los hechos, donde se encuentran periodistas (uno de ellos, Javier Chicote, reportero de investigación), un escritor de novelas policiacas y una abogada. La tertulia comienza con el conflicto del poblado chabolista, el juicio de Nadia y después el asunto de Estepona. Algunos tertulianos aportan más datos a las noticias que se debaten, pero otros se limitan a opinar y ofrecen su punto de vista. Y finalmente se da paso para ampliar el contenido de las noticias de portada.

El inicio del programa arranca con el titular: "Se produjo ayer un alarmante tiroteo en Estepona. Un hombre es llevado por la fuerza" y se reproduce con una imagen del suceso. Después, se enfoca en primer plano a la reportera desplazada a esta localidad malagueña que entra en directo, tras introducirla Casado y decirle "¿Cuál es la primera hora?". A continuación, la presentadora informa de otras dos noticias: el juicio 'Caso Nadia' y el desalojo del poblado chabolista, el cual es también tratado informativamente de forma similar a la primera noticia de portada, con un reportero desplazado en directo al asentamiento gitano, el cual señala que esta zona es conocida popularmente como "el supermercado de la droga". De nuevo, la presentadora retoma el suceso principal, diciendo "pendientes de lo que ha ocurrido en Estepona" y sale el siguiente titular "El miedo se apodera de Estepona", acompañado de imágenes con los titulares "Un tiroteo y un posible secuestro" y "¿Qué ocurrió anoche?". Cuando María Casado da paso a la última hora del desalojo de las chabolas dice "máxima tensión" y se ven las imágenes del reportero y, de fondo, las de los policías y los vecinos que se niegan a marcharse.

A mitad del programa se emite un amplio contenido informativo dedicado al problema del acoso escolar en España, entrevistando en directo en el plató a una víctima y complementado con un reportaje sobre un método antiacoso aplicado en un colegio de Madrid. Su enfoque es información de servicio público. Como vemos los sucesos tienen un posicionamiento preferente en la distribución de los contenidos del programa.

El esquema del programa es el siguiente: la presentadora va dando paso en directo a los reporteros desplazados en el lugar de los hechos para que les diga "la primera hora"; los periodistas informan sobre los mismos mientras se les enfoca en primer plano y, de fondo, las imágenes de los escenarios y posteriormente se comentan las noticias en la tertulia.

\section{Día 4 octubre}

Número total de noticias/contenidos informativos:

Del total de los 19 registros informativos computados, 6 son de sucesos (una representatividad del $31,57 \%$ ) y 5 de tribunales/sucesos (26,31\%). Si sumamos las noticias de sucesos y las de tribunales, obtenemos que más de la mitad del programa (57,89 \%) está dedicado a estas especialidades informativas que tratan sucesos. Los 8 contenidos restantes son de laboral, deporte, corazón o información rosa, economía y televisión (de ellos 3 de autopromoción de programas o producciones de la RTVE). Como vemos nuevamente, más de la mitad del programa está dedicado a sucesos. 


\section{Temática:}

Las seis noticias de sucesos son las siguientes: fallecimiento de una bebé olvidada en el coche por su padre (Madrid), dos mujeres y un hombre muertos en Coín, fallecimiento de un recién nacido por las heridas de un perro (Tenerife), asesinatos por violencia machista en España, mafias introducen a inmigrantes en coches con doble fondo (Melilla) y detención del agresor de un profesor de Sagunto. En principio, la mayoría pertenecen al ámbito de los delitos (homicidio imprudente, suicidio o asesinato, siniestro tráfico ilegal de inmigrantes y lesiones). Con respecto a las noticias de tribunales, se incluyen casos de abusos sexuales en un colegio vasco, de insultos de un juez a una presunta víctima de violencia de género, de acusación de violación de Ronaldo, 'Caso Nadia' y el juicio a un presunto estafador de Asturias.

\section{Titulares:}

Centrándonos en las seis noticias de sucesos, llevan los siguientes titulares: "Fallece una bebé olvidada en el coche. El padre está en libertad tras declarar ante la policía", "Dos mujeres y un hombre muertos en Coín. Hallan los cuerpos en descomposición", "Muere un recién nacido atacado por un perro. El niño, de 18 meses, estaba en casa con sus padres", "Violencia machista. 38 mujeres y 4 menores asesinados en lo que va de año", "Operación Azhira en Melilla. Mafias introducen 44 migrantes en coches con doble fondo" y "Última hora. Detenido el presunto agresor de Sagunto". Como ya se ha referido, los subtítulos van cambiando y en función de la actualidad. Así la noticia sobre la muerte de la bebé olvidada en el coche introduce dos subtítulos más: "La pequeña, de 21 meses, pasó 6 horas en el vehículo" y "El coche tiene los cristales tintados y no se veía a la pequeña"; en el suceso del ataque de un perro se añade: "'El perro, un pastor belga, no está considerado peligroso" y en el de Coín se subtitula "El varón apareció ahorcado en una casa de campo" y "Una de las fallecidas tenía una enfermedad terminal". Los titulares son informativos.

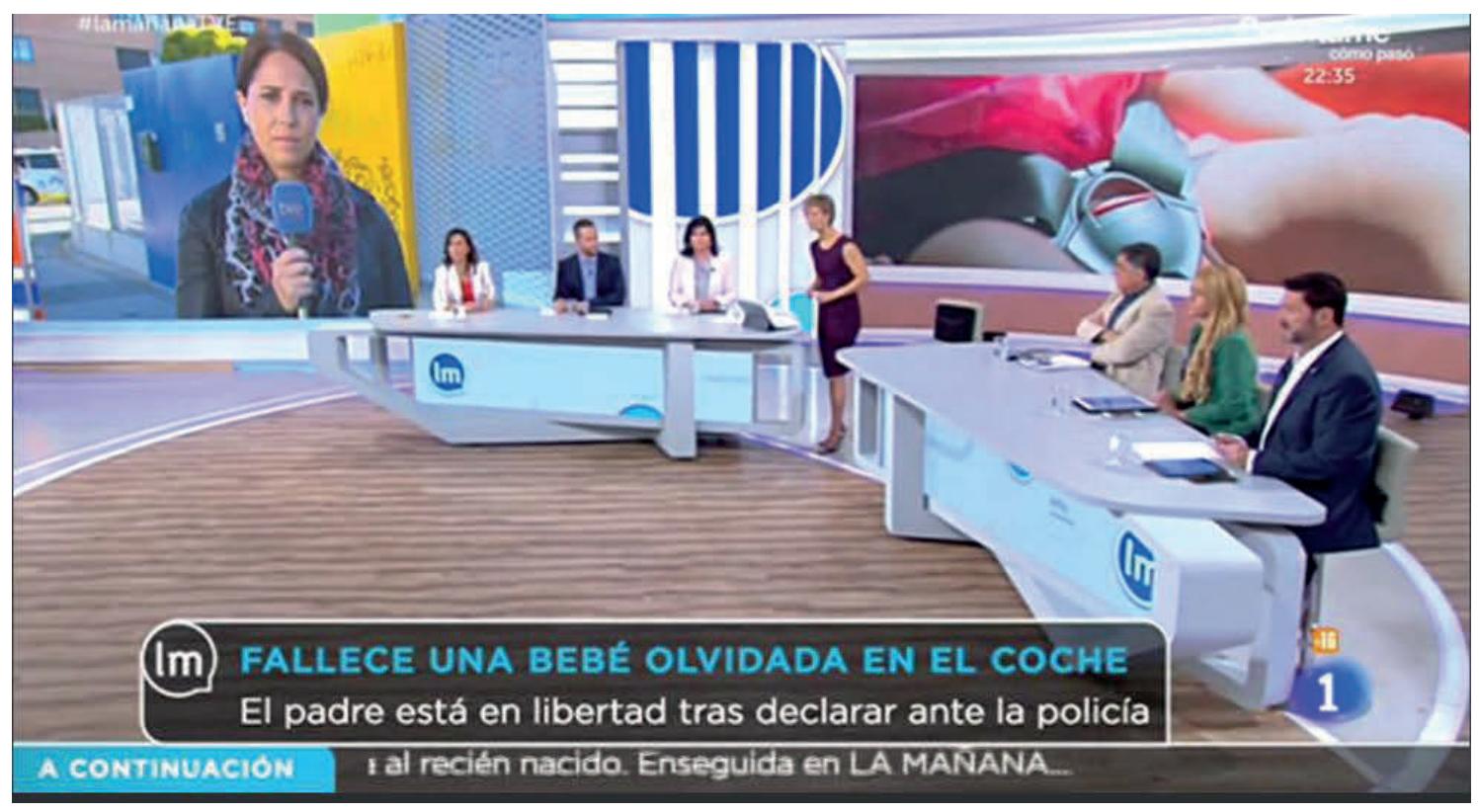

Figura 1. Programa del día 4 de octubre de 2018

Fuente: imagen capturada de La Mañana (TVE). 


\section{Fuentes:}

La noticia sobre el fallecimiento de una bebé olvidada en un coche utiliza como fuentes los datos recabados por la reportera que acude al lugar de los hechos, aunque no cita ninguna de las mismas, excepto cuando se refiere a "fuentes de la investigación" que entendemos provienen de la policía.

Las fuentes de la noticia de Coín son del escenario del suceso, ya que hay una reportera que en directo informa sobre la muerte de tres personas encontradas en una casa de campo. La periodista señala las dos hipótesis que se barajan: un caso de violencia machista o, la más probable, un suicidio colectivo, ya que una de las mujeres era enferma terminal, su suegra era muy mayor y el marido se probablemente se ahorcó. La fuente principal es la Policía Judicial, a la que se menciona de manera indirecta. La presentadora pide a la reportera datos de esa familia y, a continuación, da paso a la mesa de análisis, dirigiéndose a dos tertulianos expertos en sucesos. Interviene Juan Baño -redactor jefe de Interior de la COPE-, explicando que se trata de una investigación compleja, en fase de hipótesis y que el resultado de las autopsias revelará lo que ocurrió. Además de un criminólogo que menciona fuentes de la investigación (Guardia Civil) y aporta más datos, ya que según el testimonio del propietario de la casa de campo se calcula que los cadáveres podrían llevar dos meses muertos. Por su parte, otro de los tertulianos -una psicóloga- considera que se trata de un suicidio.

Las fuentes del reportaje sobre violencia machista son oficiales: institucionales (Ministerio del Interior y policía local) y judiciales (una sentencia). De la 'Operación Azhira' la fuente suponemos que proviene de la Guardia Civil, aunque no se cita directamente; las noticias sobre la detención del agresor de Sagunto y la del niño muerto atacado por un perro no indican las fuentes y las imágenes que aparecen no son propias de TVE. La mitad de las fuentes son oficiales (6), mayoritariamente policiales, seguidas de las judiciales y del Ministerio del Interior; y el resto son indeterminadas (6) puesto que se recaban en el lugar de los hechos, pero sin atribución y otras con atribución sólo indican "según fuentes de la investigación". En cuanto a las imágenes, ocurre algo similar, ya que una parte son propias de TVE y las otras facilitadas por las fuentes oficiales. La tertulia está integrada por tres expertos que aportan datos a algunos de los contenidos enunciados (dos son periodistas de sucesos y un criminólogo) y otros tres colaboradores que sólo añaden generalizaciones.

\section{Géneros:}

Nuevamente la noticia es el género de mayor frecuencia en la difusión de los sucesos. En menor medida se emplea el reportaje en off realizado en la redacción y la entrevista -más minoritaria- efectuada en el plató de con los protagonistas de los hechos. Los sucesos más relevantes se valoran e interpretan en el formato de tertulia (foro de debate y opinión).

\section{Tiempo:}

A los sucesos se le dedica unos 35 minutos en total, siendo la información sobre violencia de género en España la que ocupa más tiempo, seguidas de las noticias sobre las muertes de los dos bebés y el 'Caso Coín'. Los juicios tienen un espacio de unos 26 minutos y es el referido a los presuntos abusos sexuales en el Colegio Gaztelueta al que se le hace un mayor seguimiento. En total sucesos y tribunales/sucesos ocupan 61 minutos aproximadamente del total que dura el visionado del programa (1 hora y 42 minutos). Tienen una representación del 
$34,31 \%$ los sucesos y el 25,49 \% tribunales/sucesos. Por tanto, de los 102 minutos de duración cerca del $60 \%$ (un 59,80 \%) del tiempo total va dedicado a estos contenidos (más de la mitad del programa).

\section{Tratamiento:}

El programa se inicia anunciando la presentadora una noticia de sucesos: "Vamos a empezar con una terrible noticia, la muerte de una bebé, después de que su padre se la dejara olvidada durante seis horas en el coche", y conecta con la reportera en el lugar de los hechos. A continuación, María Casado da los titulares de las otras dos informaciones de portada: juicio por abusos sexuales en el colegio de Gaztelueta y una denuncia de una trabajadora que llevaba dos años sin cobrar. Un contenido es de sucesos, otro de tribunales pero con temática de sucesos y un tercero de laboral. De nuevo, es un suceso la primera noticia de la portada en este programa, que también sirve de inicio a la mesa de debate.

El copresentador, después de emitir los titulares principales, anima a la participación de los telespectadores en las redes sociales y Casado presenta a los analistas que integran la 'Mesa de la mañana', empezando con el suceso de la bebé fallecida por la imprudencia de su padre. Se trata una periodista, una psicóloga, una abogada, un periodista de investigación de El Español, otro de la COPE experto en casos policiales y un criminólogo. Se encuentran especialistas en el género que aportan más rigor al análisis de los hechos. Otros sucesos de los que se informa son la muerte de un recién nacido atacado por un perro en Tenerife y, como noticia de última hora, la detención del presunto agresor del profesor de Sagunto.

La dinámica del programa es la que hemos visto el día anterior: se anuncian tres noticias de portada y se conecta con los reporteros en el lugar de los hechos con imágenes en directo y, posteriormente, se vuelve a conectar con ellos para que cuenten los detalles. De fondo una música dinámica, de suspense, acompaña los enunciados. Las informaciones se complementan con el análisis de la tertulia.

Sobre el primer tema de portada, la presentadora le dice desde el plató a la reportera: "Cuéntanos más detalles" y, desde el lugar de los hechos va contando lo que ocurrió, donde aparece la imagen del coche donde aconteció la desgracia. Después María Casado le pregunta de nuevo: "El padre está detenido, ¿̇e qué se le podría acusar?", a lo que responde la reportera: "de homicidio imprudente". "Tremenda historia" califica Casado desde el plató y da paso a los tertulianos, diciéndoles "que a ver qué datos podéis aportar al caso". Los analistas ofrecen sus versiones e interpretaciones del suceso que se intercala en ocasiones con la intervención en directo de la reportera para dar a conocer los últimos hechos. Después el copresentador informa de otra noticia de sucesos: la muerte de un recién nacido atacado por un perro y se emite la imagen a pantalla completa de la Guardia Civil en la zona de la vivienda donde ha pasado el accidente, pero esta vez no hay desplazados reporteros.

Al igual que en el programa anterior se emite un tema de actualidad, que no noticia, enfocado como información de servicio público. Es el referido a la violencia machista que ha provocado, hasta principios de octubre de 2018, 42 asesinatos entre mujeres y niños y 38.000 denuncias por maltrato en 2017. Para ello se elaboran tres contenidos con diferentes formatos: entrevista en directo a una policía local de la Unidad de Protección de Madrid, entrevista en diferido a un responsable del sistema de seguimiento integral en los casos de violencia de género (VioGén) del Ministerio del Interior y debate sobre una sentencia judicial que rebajó la 
condena al maltratador -al entender que no hubo ensañamiento-, tras darle una paliza a su pareja. Todo ello es objeto de análisis en la tertulia.

\section{EL PROGRAMA DE ANA ROSA}

Es el magacín matinal líder de Telecinco, según recoge en su página web. También es el de mayor audiencia de los tres programas analizados en este estudio. Está conducido por la periodista Ana Rosa Quintana, la cual ha reconocido públicamente que los sucesos son la gasolina de su programa. Cuenta con un copresentador y se emite de 8:55 a 13: 30 horas. Dispone de un amplio equipo de reporteros que realizan conexiones en directo desde los lugares donde acontecen las noticias. Ha sido líder durante 14 temporadas consecutivas, cerrando en 2018 con su mejor dato de audiencia de los últimos 9 años, con una media del 18 $\%$ de share y 624.000 espectadores, superando en casi 3 puntos en su franja de emisión a su principal competidor, Espejo Público (15,3 \% y 503.000). Las secciones fuertes son 'Corazón' (se incluyen sobre todo los realities de la cadena como Sálvame y Gran Hermano), 'Política' y 'Sucesos'.

\section{Día 3 octubre}

Número total de noticias/contenidos informativos:

Del total de los 16 registros informativos computados, 3 son de sucesos $(18,75 \%)$ y 2 de tribunales/sucesos (12,5\%). El 31,25\% de los contenidos del programa se centran en informaciones de sucesos. El 68,75 \% restante se dedica a los siguientes contenidos registrados: 6 de corazón, 3 de política, 1 de internacional y 1 conexión al programa de actualidad Ya es mediodía. Los contenidos informativos más numerosos son los de corazón (37,5\%).

\section{Temática:}

Las tres informaciones de sucesos registradas pertenecen al ámbito delictivo (dos casos de homicidios y la noticia de un tiroteo con secuestro y posible asesinato). En concreto, se trata del asesinato de un hombre a cargo de su mujer en Alicante y la muerte de un niño de Sabadell manos de su padre, cometidos hace unos meses. Las dos noticias de tribunales son de temática de sucesos (estafa y sustracción de hijos), referidas a los juicios 'Nadia' y 'Juana Rivas'.

\section{Titulares:}

Las noticias de sucesos se encabezan con los titulares: "Nueva carta de la Viuda Negra de Alicante. Conchi nos envía una nueva misiva desde la cárcel", "El parricida del acantilado. El padre que estrelló el coche con su hijo iba a perder la custodia" y "Tiroteo en Estepona". Los dos primeros van identificados con la palabra en mayúscula 'Exclusiva'. Se utilizan frecuentemente los rótulos a pie de imagen, cuando se va informando de un suceso, emitiendo la imagen y abajo el titular, que va variando en función del desarrollo de los acontecimientos. Se hace uso de titulares llamativos que espectacularizan los contenidos informativos.

\section{Fuentes:}

Analizamos las tres noticias de sucesos emitidas, de las cuales dos son consideradas por el programa como exclusivas. El caso 'Viuda negra de Alicante' utiliza como fuente principal una 
carta que la presunta asesina de su marido, Concepción Martín, Conchi, ha enviado desde la cárcel a la redacción del programa. Se trata de la segunda carta que manda, ambas escritas por una compañera de celda, exculpándose del asesinato. La novedad de esta segunda carta es que la inculpada escribe ella misma una pequeña frase, diciendo que "estará encantada cuando todo termine de explicaros con todos los detalles. Muchas gracias". No aporta nada informativamente e incluso los propios tertulianos critican la falta de veracidad del contenido de la carta, pero este espacio lo vende como una exclusiva, señalando en sus titulares: "Hoy en el programa de A.R. las primeras líneas, de puño y letra, de Conchi, viuda negra".

En la primera carta que envió al programa daba su versión de los hechos, sin aún haber declarado ante el juez, explicando de forma ambigua lo que pasó en el lugar del crimen y su supuesta enfermedad. Esta información se complementa con las aportaciones que realizan los componentes de la denominada 'Mesa de Actualidad', donde analizan y opinan sobre la credibilidad de esta fuente. Uno de los tertulianos dice que esa carta "no es fiable", ya que hubo una policía testigo del asesinato imputado a Conchi y al cuidador de su marido, que también participó en la muerte. "¿Quién manda una carta a televisión después de haberse negado a declarar a un juez?", pregunta clave de un tertuliano especializado en sucesos que pone en evidencia la veracidad de la carta. Otro de los integrantes de la mesa de actualidad, un policía, también cuestiona la carta enviada a Telecinco, ya que "la presunta asesina dice que quiere ayudar a que se encuentre al asesino, pero sí te han pillado en el lugar de los hechos", además señala que "la versión policial nada tiene que ver con la de Conchi".

La fuente de la segunda noticia, el 'Caso parricida del acantilado', es una entrevista que se realiza a un amigo del homicida, en la que explica cómo era y las motivaciones que pudo tener para matar a su propio hijo. Se utilizan tres fuentes más: vecinales ("Pere era un hombre bueno, según sus vecinos, y con una nueva ilusión amorosa", así se titula), las provenientes de otro medio de comunicación (diario $A B C$ ) y dos compañeros del centro de salud donde trabajaba el asesino ("Lo conocía de vista. Sólo de hola y adiós" / "Sólo lo conocía de vista"). Se informa que los vecinos del bloque donde vivía no quieren hablar, ni tampoco la familia del suicida que ha pedido que no se hable nada. Ello se complementa con las opiniones y versiones de los tertulianos del programa.

Con respecto al tiroteo de Estepona, se facilitan imágenes en directo de Telecinco del lugar de los hechos, así como vídeos facilitados por los testigos. Hay desplazado un reportero que informa y posteriormente comenta que el secuestro estaría relacionado con un cadáver hallado en Algeciras, pero no hace mención a ningún tipo de fuente consultada. Los tertulianos consideran que se trata de un "ajuste de cuentas" por el control de las drogas en la Costa del Sol.

Las fuentes utilizadas son mayoritariamente no oficiales (8), siendo las más numerosas las vecinales, seguidas por declaraciones de amigos y compañeros de trabajo, de otros medios de comunicación y del autor de los hechos. Se recurre con mayor frecuencia a la fuente vecinal que no suele ser rigurosa por basarse en suposiciones y rumores, pero fácil de conseguir y buen recurso televisivo. También se hace uso, aunque de forma muy minoritaria, de las fuentes indeterminadas. Estos contenidos son complementados con los datos aportados por dos tertulianos expertos (un inspector de Policía y un periodista especializado en sucesos de El Español), los cuales se convierten en fuentes propias, al facilitar más información sobre los 
sucesos enunciados. El resto de tertulianos no son especialistas en la materia. Otras fuentes importantes utilizadas son las imágenes, a pantalla completa, de fotografías de la madre y el padre con el niño asesinado, sin citar quién o quiénes han facilitado este material audiovisual (fuente indeterminada), apoyado con conexiones en directo donde se entrevistan a vecinos del parricida. Con respecto al caso 'Viuda negra de Alicante', las imágenes que se emiten tampoco son en directo, sino de archivos y otras elaboradas con fotomontajes.

\section{Géneros:}

Se utilizan varios formatos periodísticos. Además de las noticias, los reportajes cortos o mini reportajes (información+ imágenes+voz en off) e información de calle (información, voz e imágenes en directo). La Mesa de Actualidad utiliza el género de la tertulia, intercalando los reportajes y la información de calle con imágenes en directo y de archivo, a pantalla completa, generalmente impactantes. La tertulia es el género más utilizado en el formato televisivo.

\section{Tiempo:}

A las tres noticias de sucesos se les dedica 31 minutos, siendo el de mayor duración el caso 'El parricida del acantilado' y después el de la 'Viuda negra de Alicante'. Por su parte, las dos informaciones de tribunales tienen una duración de 7 minutos (la que ocupa más tiempo es el juicio de los padres de Nadia). Suman un total de 38 minutos, lo que pone en evidencia que el tiempo dedicado a sucesos ocupa casi el $17 \%$ de la programación (14 \% sucesos y $3 \%$ tribunales). Duración aproximada del visionado: 222 minutos (3 horas y 42 minutos).

\section{Tratamiento:}

La presentadora, después de la tertulia política da paso al copresentador que dice "Vamos a la actualidad", centrada en temas de sucesos: los casos la 'Viuda Negra de Alicante' y el 'Parricida del acantilado'. De los tres sucesos de los que se informa sólo uno es de actualidad propiamente dicha, ya que los asesinatos que se han citado anteriormente acontecieron hace unos meses (el 20 de agosto y el 13 de septiembre de 2018, respectivamente) y ahora se tratan como exclusivas, con un enfoque sensacionalista. La única noticia que se ofrece de sucesos -enfocada como de última hora- es un tiroteo acontecido en Estepona y el posterior secuestro en mitad de la calle.

Especialmente destacable es el caso 'Viuda Negra', sobre todo en el tratamiento audiovisual que se hace del mismo (tanto por las imágenes, incluidos los fotomontajes que aparecen, como por la música ambiental empleada). Si analizamos el contenido informativo, observamos que se le dedica un total de 12 minutos -que es mucho en televisión- a una noticia que realmente no es tal. Es decir, la presunta coautora del asesinato cometido contra su marido que se encuentra en la cárcel a la espera de juicio-, envía una carta al programa para explicar su versión de los hechos. Lo que llama la atención es que se vende como exclusiva que "Hoy en el Programa de AR las primeras líneas, de puño y letra, de Conchi, la viuda negra". La inculpada escribe una frase diciendo "que estará encantada cuando todo termine de explicaros con todo detalle. Muchas gracias".

En el resto de la carta -escrita por otra compañera de celda- defiende su inocencia. Como vemos, desde el punto de vista periodístico, no aporta nada al caso, sólo publicidad a la supuesta homicida, pero en este programa se convierte en un buen recurso televisivo para rellenar 12 minutos de emisión. Además, se da la circunstancia de que Conchi no ha querido 
declarar ante el juez, pero sí ante un programa de televisión. Es la segunda carta que manda y que se vende como exclusiva la cuestionable novedad que supone que en esta ocasión la imputada ha escrito ella misma una frase.

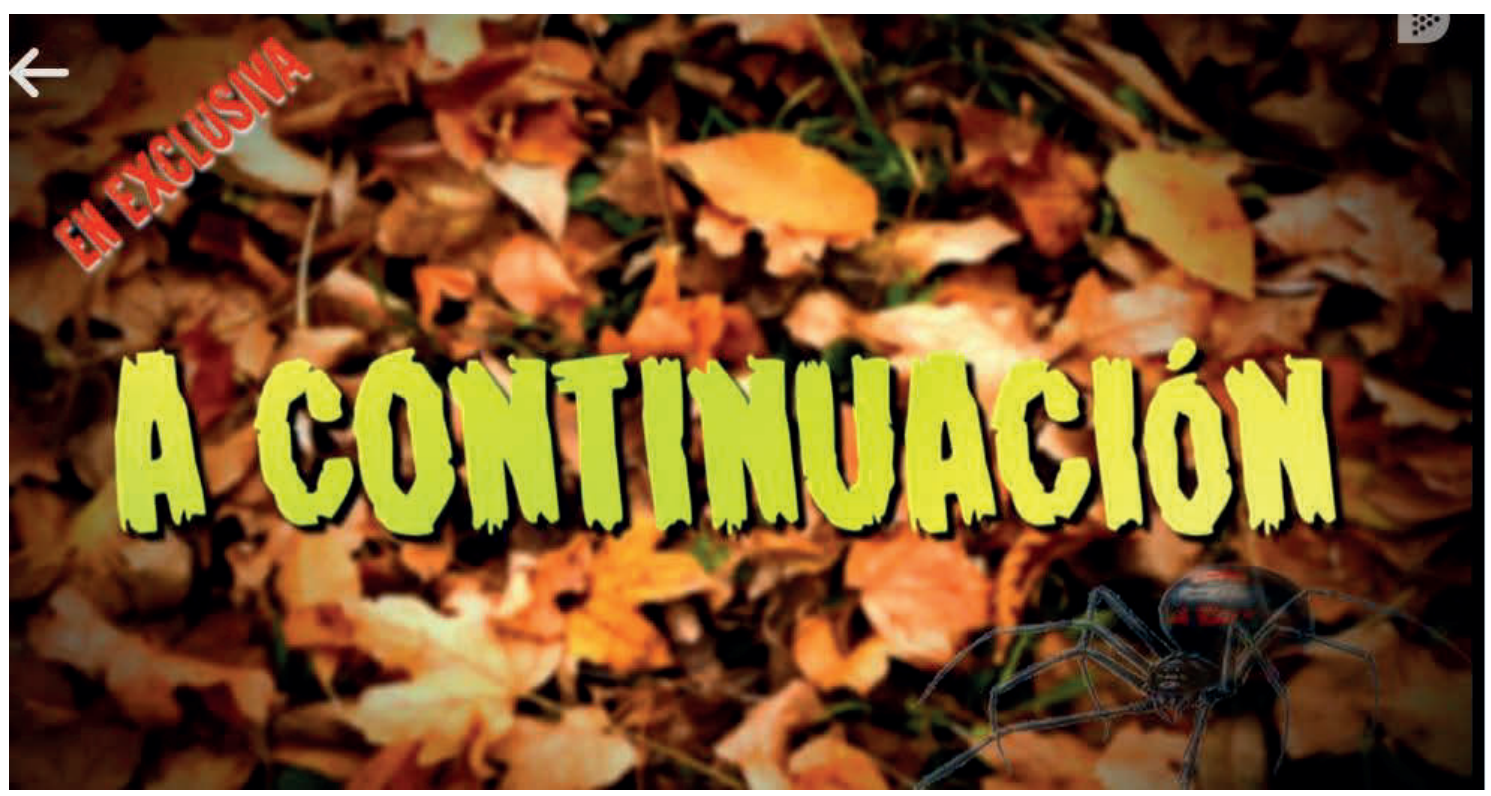

Figuras 2. Programa del día $\mathbf{3}$ de octubre de $\mathbf{2 0 1 8}$

Fuente: imágenes capturadas de El Programa de AR (Tele 5).

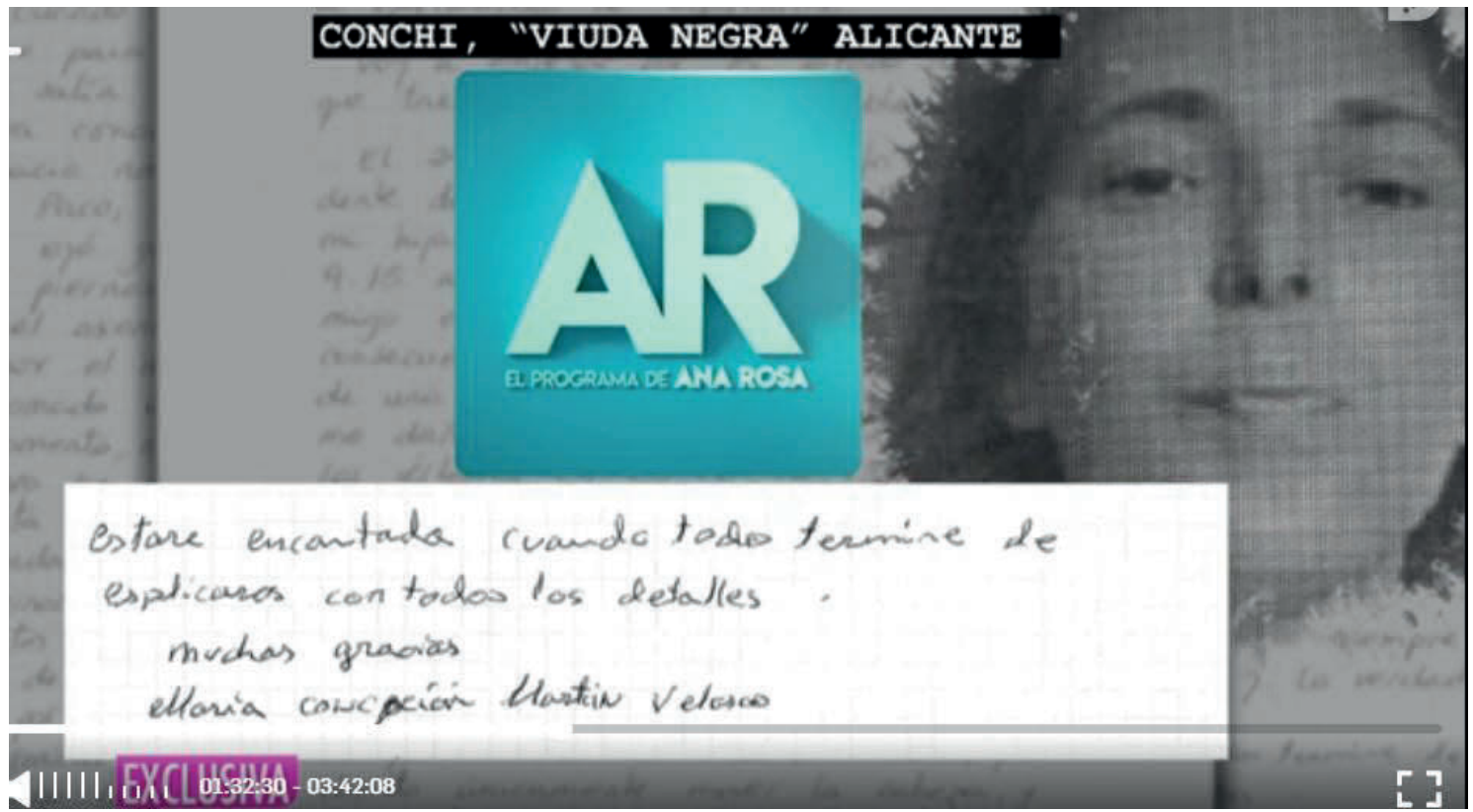

Figuras 3. Programa del día 3 de octubre de 2018

Fuente: imágenes capturadas de EI Programa de AR (Tele 5).

La exclusiva del 'Parricida del acantilado' es la emisión de una entrevista a un amigo del autor de la muerte del niño de Sabadell que aparece con la voz distorsionada, con una duración de un minuto, en la que cuenta cómo era el homicida y la posible motivación de su crimen. Se da paso a otro tema y posteriormente se retoma en la 'Mesa de Actualidad', dedicándole 16 minutos. Se emite un pequeño reportaje en el que se cuenta que fue el pasado 13 de septiembre cuando el padre mató al hijo, estrellándolo en Francia contra un barranco, porque 
no consentía perder la custodia del niño. De nuevo aparece la tertulia, comentando la presentadora que "no existe circunstancia alguna que pueda justificar que un padre arranque la vida a su hijo", porque al parecer tenía trastorno bipolar. Una tertuliana dice que el que "mata no está mal de la cabeza. No busquemos trastornos donde no los hay". Otro periodista opina que este suceso tiene que ver con "hacer daño de por vida a la mujer, a la madre del niño asesinado". Estos comentarios, que no aportan nada al caso, se complementan informativamente con conexiones en directo de una reportera que acude al barrio de Sabadell donde vivía el parricida y consigue declaraciones superficiales de los vecinos y compañeros de trabajo. Nuevamente se da paso a la tertulia, en la que comenta Ana Rosa: "Este hombre lo que quería al final era hacer daño a su mujer. Pues tío, itírate tú por el barranco!".

\section{Día 4 octubre}

Número total de noticias/contenidos informativos:

Del total de los 21 registros 3 son de sucesos y 3 de tribunales/sucesos. Ambos contenidos representan un 28,57 \%. El resto de contenidos son los siguientes: 7 de corazón (1 de ellos es autopromoción 'Gala Sálvame'), 3 de economía, 3 de política, 1 de deportes y 1 de conexión al programa 'Ya es Mediodía'. Por tanto, más del $28 \%$ de los contenidos del programa se centran en noticias de sucesos y más del 71 \% en otras informaciones (prevaleciendo en un 33,33\% las de corazón o información rosa).

\section{Temática:}

Las tres noticias de sucesos se refieren a la muerte accidental de una niña olvidada por su padre en un coche en Madrid, la agresión sufrida por un profesor de un colegio de Sagunto y el hallazgo en Algeciras del cadáver de un narco secuestrado el día anterior tras un tiroteo en Estepona. Además, se emiten tres informaciones sobre los juicios 'Caso Nadia', 'Caso Juana Rivas' y los insultos de un juez a una víctima en un caso de violencia contra la mujer. Las tres noticias de sucesos registradas pertenecen al ámbito delictivo (un presunto homicidio imprudente, otro de lesiones y un posible asesinato). Las de tribunales tratan temas de estafa, secuestro de hijos y malos tratos.

\section{Titulares:}

Las tres noticias de sucesos se encabezan con los titulares: "Muere una niña olvidada en un coche. Su padre se despistó y no la dejó en la guardería antes de ir al trabajo", "Agresión en un colegio de Valencia. El padre de una niña de 9 años agrede y amenaza de muerte a un profesor" y "Tiroteo en Málaga, cadáver en Cádiz. El narco asesinado es Brian, de 27 años y residente en Cádiz".

Como vemos aparecen -a modo de rótulos informativos en la pantalla- los títulos principales, con letras en mayúscula, complementados con los subtítulos que se van actualizando, según el desarrollo de las noticias. Ejemplo: "Detienen al padre que agredió al profesor". En los antetítulos se señala el lugar de los hechos y se especifica si se trata de última hora o retransmisión en directo. Son visualmente llamativos y con distintos fondos de colores que resaltan el contenido. En general son titulares informativos, excepto el encabezado por "Tiroteo en Málaga, cadáver en Cádiz" que tiene un enfoque más interpretativo e impactante.

\section{Fuentes:}


La información que se emite sobre la agresión a un profesor se nutre de las declaraciones recogidas por un reportero de AR a la propia víctima, al director del colegio, a los padres afectados, así como los datos recabados en el lugar de los hechos y de la agencia Europa Press. Son mayoritariamente fuentes propias y no oficiales. Un reportero en directo entrevista al profesor para que ofrezca su versión de los hechos, ocupando la imagen a toda la pantalla y luego también aparecen los rostros de los padres del colegio pidiendo protección. Desde el plató varios tertulianos preguntan al profesor sobre si conocía al agresor y cuál fue el castigo que le impuso a la niña. En este caso, se acude a una fuente principal, como es la víctima, y a otras secundarias del centro educativo. Este suceso se nutre de buenas fuentes para contar los hechos de manera informativa y posteriormente son comentados en una mesa de debate en la que ninguno de los que ofrecen sus opiniones son especialistas en sucesos. Ejemplo: uno de los colaboradores opina que "hace falta diálogo" y la presentadora sentencia que "la solución no es el castigo".

Con respecto a las fuentes empleadas en el suceso sobre la muerte de la niña olvidada en el coche, se encuentran los datos conseguidos por la reportera que acude al lugar de los hechos, señalando que el padre ha sido puesto en libertad tras prestar declaración y se muestran repetitivamente las imágenes del coche. La información se complementa con la emisión en diferido de un breve reportaje que señala las circunstancias en las que supuestamente pudo suceder la tragedia, a través de entrevistas a los vecinos y la policía. Se da paso a la tertulia en la que varios expertos en sucesos analizan cómo pudo ocurrir el suceso.

La tercera noticia, el tiroteo en Estepona, se ilustra con las imágenes ofrecidas por la cadena loca, así como de un vídeo facilitado por alguna de las personas que estaban en el restaurante y las voces en off de los testigos. Se refuerza la información con los datos obtenidos por un reportero de AR y que incluye las declaraciones de los testigos (los trabajadores del Burguer King y las personas que presenciaron el secuestro), fuentes de la investigación (policial) y un representante vecinal de una asociación de Marbella que se queja de la inseguridad ciudadana y el narcotráfico en la Costa del Sol. Este asunto sirve de motivo para que en el plató los tertulianos comenten sobre las mafias que operan en la provincia de Málaga, y uno de los periodistas especializados de la mesa aporta el dato, consultado a fuentes policiales, que le confirman que "se están produciendo muchos ajustes de cuentas y robos entre los narcos". Como recurso documental, se retoman unas declaraciones de un narcotraficante, que hizo a Ana Rosa en exclusiva en un programa anterior, y sobre esta fuente se emite un reportaje sobre esta temática, recogiéndose un titular de $A B C$. Además, se añaden imágenes y fotografías facilitadas por la Guardia Civil donde aparece Brian, el presunto narco secuestrado y asesinado. Este suceso está bien documentado, complementándose con la problemática del narcotráfico en la Costa del Sol, ya que utiliza fuentes de los testigos, policiales e imágenes del lugar de los hechos.

En las 18 fuentes utilizadas en los tres sucesos prevalen mayoritariamente las no oficiales (vecinales, testigos, compañeros y allegados de las víctimas, víctima y otros medios de comunicación) frente a las oficiales (todas policiales). También, destacar que los tres sucesos son cubiertos en el entorno de los hechos, haciendo uso de la fuente indeterminada ("según fuentes de la investigación"). Las imágenes que se emiten son en gran parte en directo recabadas por las cámaras de Telecinco en el lugar de los hechos, una de archivo para documentar un suceso, así como otras facilitadas por otro medio de comunicación y el vídeo 
de los testigos. La aportación de los tertulianos se basa en comentarios, conjeturas y opiniones, excepto uno de ellos, un periodista especializado que aporta datos recabados de "fuentes policiales". En este sentido, hay que indicar que la tertulia está compuesta dos periodistas de sucesos y un policía, pero el resto no con colaboradores expertos en esta temática.

\section{Géneros:}

Se utilizan varios formatos periodísticos. Breves noticias de introducción, reportajes cortos (información de calle, imágenes en directo y de archivo) y crónica (recreación de los hechos+información+interpretación+imágenes+voz en off). La Mesa de Actualidad emplea el género de la tertulia (opinión+análisis), intercalando los reportajes y la información con imágenes impactantes y titulares llamativos que espectacularizan los contenidos. Son el reportaje y la tertulia los géneros que más se emplean en el magacín.

\section{Tiempo:}

A las tres noticias de sucesos se les dedica más de 29 minutos (la amplia información sobre el tiroteo de Estepona y posterior hallazgo en Cádiz del hombre secuestrado y su relación con el narcotráfico es la noticia que contabiliza más tiempo de emisión). Por su parte, las informaciones de tribunales tienen una duración de 11 minutos, siendo el juicio de Juana Rivas el que tiene más espacio). Suman un total de 40 minutos, lo que pone de manifiesto que el tiempo dedicado a los contenidos de sucesos ocupa el $18 \%$ de la programación ( $13 \%$ sucesos y $5 \%$ tribunales). Duración del visionado: 222 minutos (3 horas y 42 minutos).

\section{Tratamiento:}

La primera noticia de apertura es un suceso: la muerte de una niña olvidada en el coche por su padre. Ana Rosa Quintana da paso, en directo, a una reportera para que explique brevemente lo sucedido, la cual señala que es un "suceso inexplicable". Luego se tratan otros contenidos de tribunales, política y economía y, a continuación, se entra de nuevo en el ámbito de los sucesos con el enunciado de que el padre de una alumna agrede a su profesor, ofreciendo un breve reportaje con las declaraciones e imágenes de la víctima, el colegio y los padres.

El tratamiento es informativo, pero, una vez se da paso a la tertulia, aparece el análisis y la opinión, haciéndose notar que los comentaristas no son especialistas en sucesos.

La muerte de la niña tiene también un enfoque periodístico eminentemente informativo, por parte de la reportera que comienza señalando que se trata de una "tragedia" y acaba diciendo, a modo de reflexión: "¿Cómo pudo ocurrir algo así?", para dar paso a la tertulia. Todo ello se complementa con imágenes a pantalla completa del coche $y$, de fondo, una música de suspense. Durante la tertulia aparece el rótulo fijo: "Muere niña olvidada en un coche".

A continuación, el copresentador introduce la tercera noticia de sucesos encabezada bajo el título "Tiroteo en Málaga, cadáver en Cádiz" y anuncia que "todos los demás detalles después de publicidad". Se dirige a los televidentes para decirles que se van aclarando los hechos de lo que ha pasado y se emite un breve reportaje en diferido con las imágenes del tiroteo. "Martes, 11 de la noche, el pánico cunde en Estepona. Toda esta gente acaba de presenciar una escena de película", así comienza el reportaje. Luego aparece en directo el reportero que gestualiza dirigiéndose a la cámara cuando explica los hechos, así como otras imágenes que muestran los 
testimonios del tiroteo y dos fotos de la persona asesinada conocida como Brian Carmona, finalizando la con la siguiente frase del periodista: "La Costa del Sol vuelve de nuevo a sufrir las consecuencias del crimen organizado". En el plató Ana Rosa le comenta al reportero que "no es la primera vez que ocurren estos hechos", el cual responde afirmativamente.

Este argumento sirve para que el reportero entreviste en directo a un representante de una asociación vecinal, al parecer muy conocedor de la Costa del Sol, que se queja de la inseguridad ciudadana. Ana Rosa desde el plató le hace varias preguntas relacionadas con el narcotráfico en Marbella, Estepona y Tarifa. Es decir, que esta entrevista, que se intercala con los comentarios de los tertulianos, sirve para introducir la temática de las mafias que operan en la zona y sus "modus operandi", que sirve de complemento al suceso ocurrido por su relación con el ajuste de cuentas por robos entre los narcos.

La evolución de la noticia permite complementarla con la temática del narcotráfico en la Costa del Sol que da más juego al formato del programa. El tratamiento periodístico es más de crónica, con la recreación de los hechos, comentarios más interpretativos, imágenes repetidas, titulares más sensacionalistas y la tertulia más centrada a analizar el asunto del narcotráfico con la imagen a pantalla completa del presunto narco asesinado. Se intercalan las imágenes de los tertulianos con las de la víctima, las facilitadas por la Guardia Civil y del vídeo del tiroteo, repitiéndose una y otra vez.

\section{ESPEJO PÚBLICO}

Es uno de los programas estrella de Antena 3. Se centra en temas de actualidad, especialmente política, economía, sucesos, tribunales y corazón. Comenzó a emitirse los domingos del año 1996 con reportajes. Ha pasado por diferentes etapas y presentadores. A partir de 2006 lo presenta la periodista Susana Griso, emitiéndose por las mañanas, de lunes a viernes, en horario de 9:00 a 13:30 horas. Este magacín se centra en la actualidad con la emisión de noticias y reportajes, complementados con tertulias y debates. Cuenta con colaboradores fijos especializados en sucesos, como son los periodistas Alfonso Egea² -coordinador de la sección de investigación y sucesos del programa- y Nacho Abad, también criminólogo.

\section{Día 3 octubre}

\section{Número total de noticias/contenidos informativos:}

Del total de los 19 contenidos informativos registrados, 3 son de sucesos $(15,78 \%)$ y 1 de tribunales con temática de sucesos. Si sumamos ambos contenidos el $21 \%$ del programa se centra en sucesos. El resto de contenidos (el 79 \%) son de política (9), economía (3), autopromoción de Atresmedia (2) y conexión a Informativos (1). Comprobamos que la temática política tiene una alta representación (más del $47 \%$ ) en el total de contenidos emitidos.

\footnotetext{
${ }^{2}$ Unicorn Content, empresa audiovisual de la comunicadora de Mediaset España, ha contratado a Alfonso Egea para trabajar en la nueva temporada de 2021 en programas como El programa de Ana Rosa y Ya es mediodía, en Telecinco y 'Cuatro al día en Cuatro. Tras 11 años trabajando en Espejo Público ha cambiado de empresa, aunque seguirá informando sobre sucesos.
} 


\section{Temática:}

La temática de las informaciones sobre sucesos que se difunden son el desalojo policial de un poblado chabolista de Son Banya (Palma de Mallorca) por temas de narcotráfico, un tiroteo y posterior secuestro en Estepona de un hombre y un crimen no resuelto de un anciano ocurrido en el 4 de febrero de 2017 en Santander. En tribunales/sucesos, se hace el seguimiento al 'Caso Nadia' que se juzga por una estafa. Todos son delitos.

\section{Titulares:}

Los titulares principales que encabezan las tres noticias de sucesos son: "Ultima hora. Tensión en Son Banya. Se reanudan los derribos de Son Banya. ¿Cómo van a reaccionar los vecinos?", "Ultima hora. Secuestro en Estepona. Investigan un tiroteo y un posible secuestro en mitad de la calle de Estepona" y "Llamada del crimen. Hablamos con el inspector que investiga la llamada clave del crimen". Durante el programa van cambiando los titulares, en función de cómo se van desarrollando los acontecimientos. Así se refleja, por ejemplo, en el suceso de Estepona: "Ultima hora. Tiroteo en Estepona". Subtítulos: "Varios encapuchados secuestran a un hombre a tiros en plena calle de Estepona", "Les contamos la última hora del violento secuestro en Estepona", "Una testigo del tiroteo nos cuenta la escena de pánico que se vivió", "Testigo: varios encapuchados le han dado una paliza y se lo han llevado".

\section{Fuentes:}

La noticia de Son Banya es cubierta en directo por una reportera, que cuenta lo que está pasando, entrevistando a algunos de los vecinos afectados y también se emiten imágenes de Antena 3 donde se puede ver el poblado y la Policía Nacional con los furgones procediendo al desalojo a las personas que viven en las chabolas.

Con respecto al tiroteo en Estepona, la información se nutre de los testimonios y las imágenes de los testigos (vídeos grabados de sus móviles), junto a fuentes policiales que ofrecen la última hora referida al hallazgo de un cadáver en Algeciras que, según las hipótesis, podría ser del hombre secuestrado. También hay desplegado un reportero de calle en la localidad malagueña que informa en directo y se emiten varias declaraciones de los testigos del tiroteo, así como de fuentes vecinales próximas al escenario y un comunicado de emisoras policiales.

El tercer suceso emitido es el denominado 'La llamada del crimen', referido al asesinato de un octogenario ocurrido en Santander en 2017. El programa anuncia como novedad informativa que una llamada anónima -cuyo audio ha difundido la Policía Nacional a los medios-, puede ser clave para la resolución del caso. La fuente que aporta Espejo Público para ampliar la información es una entrevista realizada a un inspector que investiga este caso.

Las fuentes empleadas (unas 15 aproximadamente) son en su mayoría no oficiales (protagonistas de los hechos, testigos directos y vecinos), seguidas de las oficiales (policiales) y una indeterminada con atribución ("fuentes de la investigación"). Las imágenes en directo grabadas por Antena 3 son fuentes relevantes que destacar, en especial en el caso del conflicto en las chabolas de Son Banya, así como los vídeos subidos a las redes sociales por los propios testigos del tiroteo de Estepona. 


\section{Género:}

Se utilizan varios formatos periodísticos. Reportaje cortos o mini reportajes (información+ imágenes+voz en off), información de calle (locución e imágenes en directo+entrevistas) y tertulia (opinión+interpretación). La llamada Mesa de Actualidad utiliza el género de la tertulia, intercalando los reportajes y la información de calle con imágenes en directo, a pantalla o de archivo, generalmente impactantes y titulares llamativos que espectacularizan los contenidos informativos. Es la tertulia el género que más tiempo se le dedica en el programa.

\section{Tiempo:}

Se dedican 28 minutos a sucesos (secuestro Estepona 6, desalojo policial del poblado de Son Banya 17 y teléfono crimen 5) y 15 al juicio 'Caso Nadia'. En total unos 43 minutos, del total de los 224 minutos que tiene la duración del visionado del programa. Los sucesos ocupan casi un $12,5 \%$ del espacio del programa que unido al total de tiempo dedicado a tribunales/sucesos representa un porcentaje del $19,19 \%$.

\section{Tratamiento:}

Las tres primeras noticias de apertura del programa son de temática política, la cuarta de tribunales (juicio 'Caso Nadia') y la quinta de sucesos (conflicto por el desalojo de un poblado chabolista dedicado al tráfico de drogas).

El desalojo de Son Banya es el suceso que ocupa más espacio de los tres emitidos, con imágenes en directo del lugar de los hechos, los vecinos y la Policía. Después de la sección 'Un café con Susana' -que aparece al principio del programa y donde se suele entrevistar a políticos-, se anuncia el juicio sobre el 'Caso Nadia' y, a continuación, como noticia de última hora, la tensión en Son Banya con el interrogante: "¿Cómo van a reaccionar los vecinos?", ante la reanudación del desalojo y posterior derribo de este poblado. Susana Griso da paso a la reportera de calle que ofrece un enfoque informativo, incidiendo en que los vecinos se resisten a dejar el poblado y "la emprenden contra los medios" que cubren los hechos. El copresentador complementa la información periodística ofreciendo imágenes en directo de la cadena, tanto de fondo como a pantalla completa, donde se muestra el escenario del conflicto.

Este suceso se vuelve a retomar posteriormente, insistiendo la presentadora en la tensión "que se vive hoy en Mallorca", debido a que los vecinos no están "por la labor de que se desmantele el asentamiento chabolista". El copresentador hace el siguiente comentario sensacionalista desde el estudio: "Aquí hoy va ver sangre, pistolas, pistolas, pistolas... porque quieren evitar a toda costa que se derriben más casas dentro del poblado". Se produce una nueva conexión en directo con la reportera a la cual se le pregunta desde el plató si hay tensión, aunque su imagen no aparece sino la principal, a pantalla completa del poblado, los vecinos y la policía con los furgones. La respuesta es que "los vecinos están muy enfadados, en pie de guerra porque no quieren perder sus casas" y si se las destruyen tendrán que ocupar otras viviendas.

Como vemos, el enfoque que se ofrece en todo momento es la tensión existente, los testimonios de los vecinos, pero en ningún caso se recoge la versión policial, ya que se trata de un desalojo por orden judicial. Apenas se menciona el hecho de que es un lugar dominado por clanes dedicados al tráfico de drogas. Se tiende a la dramatización del conflicto y a ofrecer una visión con falta de rigor a los telespectadores, más favorable a la situación de los vecinos que 
al hecho de contar de que se trata de una medida legal de lucha contra el narcotráfico. Finalmente, la periodista indica que: "De momento, ahora hay calma. Estamos pendientes de contaros cómo avanza la mañana y los trabajos de derribo de las casas".

El secuestro a tiros de un hombre en Estepona tiene un tratamiento más secundario con respecto al anterior, aunque también adquiere relevancia en el programa, al convertirse en la séptima noticia que se emite considerada de 'Ultima hora'. La presentadora dice: "Nos llegan imágenes de un tiroteo en Estepona, es una información de última hora, cuéntanos". El copresentador amplía los hechos y se emite a pantalla completa las declaraciones de los vecinos, diciendo a continuación: "Susana, acabamos de conocer otra última hora que tiene mucha relación con ésta, ya que nos informan que la Policía ha hallado un cadáver esta madrugada en Algeciras y que, por proximidad geográfica, podría estar relacionado". Aclara que la Policía baraja la "hipótesis" de que puede ser la misma persona, añadiendo además el dato de que las mismas fuentes de la investigación han indicado que en la Costa del Sol se han producido en los últimos meses varios ajustes de cuentas. Todo ello acompañado por una música ambiental fuerte e impactante. Posteriormente se vuelve a retomar este caso de la mano del especialista de sucesos del programa, Alfonso Egea, el cual hace una crónica de los hechos.

Con respecto al asesinato de Santander cometido en 2017 -denominado en el programa 'La llamada del crimen'-, se trata de un caso no resuelto porque se desconoce su autoría. Ya se había hecho seguimiento sobre este suceso en programas anteriores -el 27 de septiembre de 2018 titulaba como novedad que "Espejo Público localiza la cabina desde la que se hizo la llamada clave del crimen de Santander"- y en la emisión del 3 de octubre se vuelve a enfocar como novedad por la aportación de nuevos datos ofrecidos a Antena 3 por el inspector que investiga la llamada anónima y al cual se entrevista. Puesto que fue la Policía Nacional la que facilitó el audio a los medios, dicha entrevista es considerada por el programa no sólo como de interés periodístico, sino como una información de servicio público para ayudar al esclarecimiento de los hechos e implicar a los espectadores a localizar a la persona que realizó la llamada.

Audiovisualmente figura a pantalla completa el título en letras grandes y mayúsculas 'LA LLAMADA DEL CRIMEN', se escucha la voz en off de la llamada anónima y otras que se escuchan de fondo y se anuncia a continuación a los telespectadores el mensaje: "Hablamos con el inspector que investiga la llamada clave del crimen". Después de la entrevista, la presentadora aprovecha para hacer autopromoción del programa diciendo que Egea ha sido premiado por la Comisaría de Madrid por su labor periodística.

\section{Día 4 octubre}

Número total de noticias/contenidos informativos:

Del total de los 21 registros informativos computados, 7 son de política, 5 de sucesos, 3 tribunales/sucesos, 3 de economía, 1 tribunales/política, 1 de sociedad y 1 autopromoción Atresmedia. Cerca del $24 \%$ de los contenidos del programa se basan en noticias de sucesos. Si sumamos sucesos y tribunales, el porcentaje se eleva al 38,09 \%. 


\section{Temática:}

Los cinco sucesos emitidos tratan temáticas delictivas: muerte de una bebé en Madrid, incautación de una maleta por presunto blanqueo de capitales, agresión a un profesor en Sagunto, tiroteo y posterior asesinato de un narcotraficante y el traslado de prisión de las condenadas por el 'Crimen Isabel Carrasco'. En cuanto las informaciones judiciales, se difunden los casos 'Nadia' y 'Mauricia, madre sexagenaria' y otro sobre violencia contra la mujer.

\section{Titulares:}

Los cinco sucesos llevan como títulos principales: "Tragedia bebé olvidada. Detienen por homicidio imprudente al padre de la niña olvidada en el coche", "Última hora. Una maleta millonaria. La Guardia Civil se incauta de un millón de euros en una maleta en El Prat", "Última hora. Tiroteo en Estepona. Identificado el secuestrador en Estepona: es un narcotraficante valenciano", "¿Aulas o campos de batalla? Los profesores de un colegio de Sagunto nos confiesan que tienen miedo" y "Última hora. Asesinato de Isabel Carrasco. Las condenadas serán trasladadas a un centro penitenciario de Asturias". Como vemos, se resalta especialmente el hecho de ser noticias de última hora y el texto de algunos rótulos televisivos tienden a ser más cinematográficos que informativos.

\section{Fuentes:}

Prevalecen mayoritariamente las fuentes propias frente a las institucionales, así como las opiniones y comentarios de los tertulianos. De este modo, los diferentes sucesos se nutren con las declaraciones al programa de los padres de la guardería, la Guardia Civil y Policía Nacional, testigos, periódicos locales, la víctima (el maestro agredido en Sagunto) y la autora (emisión de las declaraciones, de archivo de Antena 3, de la asesina de Isabel Carrasco). Dos de los sucesos están cubiertos desde el lugar de los hechos, lo cual aporta un añadido de calidad informativa al reflejar de manera más directa el ambiente y entorno.

El programa se nutre de unas 13 fuentes, de las cuales sólo 2 son oficiales (policiales) y el resto no oficiales (testigos, protagonistas de los hechos, compañeros y allegados y periódicos locales) y una fuente indeterminada. Todo ello complementado con las imágenes en directo de algunos sucesos, mientas que el resto se emiten con imágenes de archivo, cedidas por la Guardia Civil, provenientes de portadas de prensa local o vídeos colgados en redes sociales. 


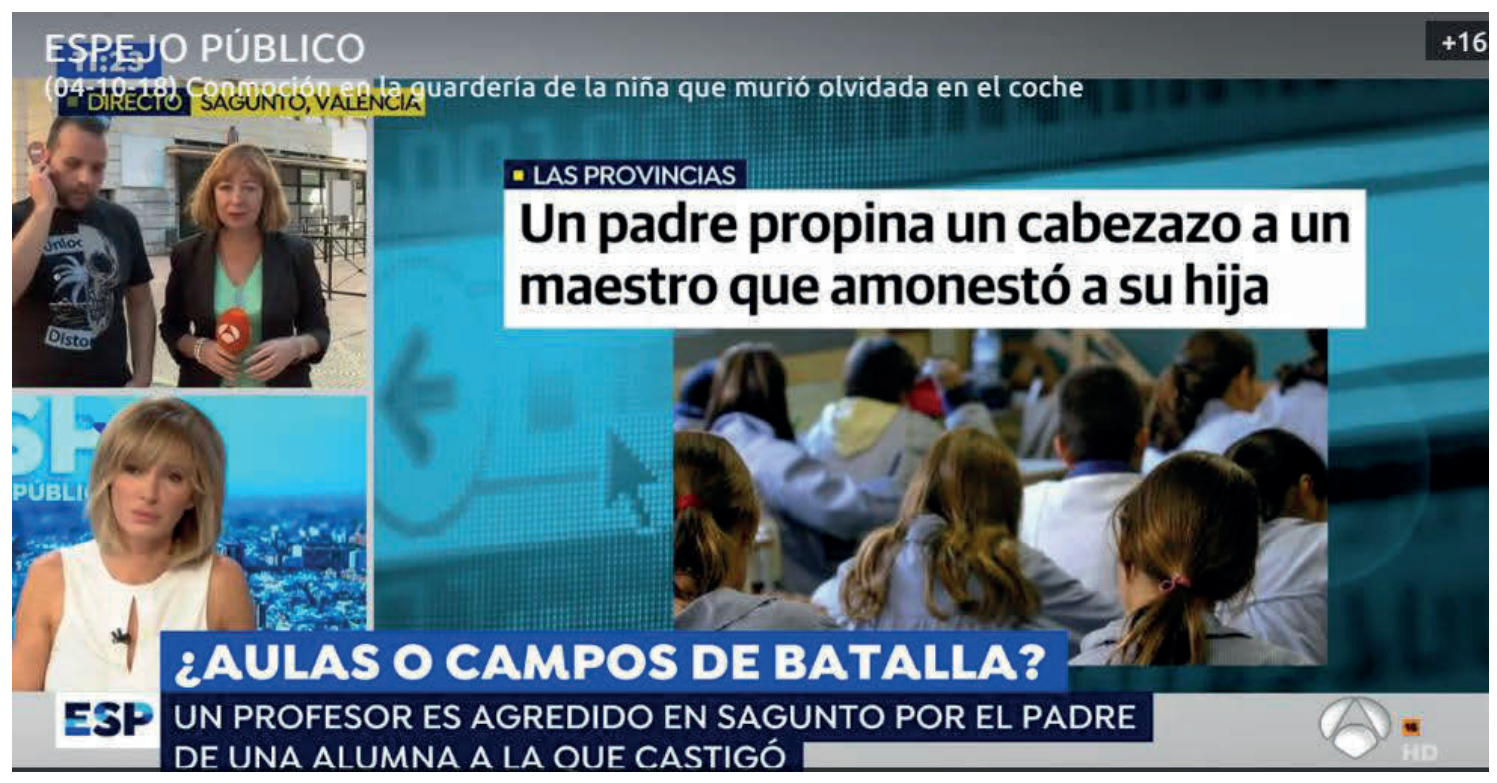

Figura 4. Programa del día 4 de octubre de 2018

Fuente: imagen capturada de Espejo Público (Antena 3).

\section{Género:}

La cobertura en directo desde la calle de dos sucesos (Madrid y Sagunto) se realiza a través de la información, las entrevistas y los reportajes. El resto son tratados como noticias, pero desde el plató. En todos los sucesos emitidos se complementa y combina la información con el análisis y la opinión sobre los hechos en la tertulia del programa. Por tanto, se mezclan los géneros informativos (noticias+reportajes) con los interpretativos y de opinión.

\section{Tiempo:}

20 minutos dedicados a sucesos (los sucesos de la tragedia de la bebé y la agresión a un profesor son los de mayor duración, 9' y 8', respectivamente; a los demás sólo se les dedica un minuto) y 33 al judicial (el caso 'Nadia' ocupa 22 minutos de emisión). Lo que supone unos 53 minutos del total de duración de los 224' de visionado del programa. Vemos pues que, en conjunto, el tratamiento sobre estos contenidos ocupa casi una hora de emisión del programa. Porcentualmente equivale al $23,60 \%$ del espacio del programa.

\section{Tratamiento:}

Las tres primeras noticias de portada no están dedicadas a sucesos, sino a tribunales, política y economía. Sin embargo, la quinta noticia de apertura es un suceso: el fallecimiento de una niña de 21 meses que su padre dejó olvidada en el coche durante casi 8 horas, a una temperatura exterior de 29 grados. La cuarta noticia es el juicio del 'Caso Nadia', también de temática de sucesos, aunque pertenece al ámbito de tribunales. La mayoría de las noticias que ofrece el programa de 'Última hora' son de sucesos e interrumpen la tertulia para dar paso a estas informaciones. De los cinco sucesos emitidos dos se cubren desplazando a reporteros al lugar de los hechos (Madrid y Sagunto), con conexiones en directo desde el programa y entrevistas a testigos o a la víctima y posteriormente análisis en la tertulia. El resto de sucesos son tratados desde el plató, tanto por el compañero que lleva las informaciones de última hora como por los expertos en sucesos de Espejo Público. 
Bajo el rótulo 'TRAGEDIA BEBÉ OLVIDADA', se informa a primera hora, durante un minuto, sobre la detención en Madrid por homicidio imprudente del padre de la niña pequeña olvidada en el coche. Dice la presentadora "Terrible noticia" y Nacho Abad, colaborador y especializado en sucesos, añade: "Terrible, terrible noticia". Luego, aparece a pantalla completa la imagen del periodista contando este suceso que se nutre de las declaraciones de los padres y las madres de la guardería donde iba la niña fallecida. Posteriormente se vuelve a retomar esta noticia, dedicándole dos minutos, con la fórmula habitual de estos formatos televisivos: información+opinión+reportaje. Desde el plató se emite nuevamente el rótulo complementado con los siguientes titulares: "¿Qué le pasó al padre de la pequeña para olvidarla?" y "El padre había llevado a sus otras hijas y se olvidó de la pequeña". Nacho Abad interviene, explicando lo ocurrido con una infografía. De fondo una música ambiental de tragedia y de alarma. A continuación, se conecta en directo con la reportera en el escenario de los hechos, ocupando a pantalla completa la imagen del exterior del colegio y del coche donde la niña murió asfixiada.

Se da paso a la 'Mesa de Debate' y la presentadora abre la misma preguntándole a un ex ministro de Justicia sobre este asunto. Además, intervienen periodistas no especializados en sucesos, excepto Abad, el cual interpreta cómo pudo pasar este suceso y comentando que el padre "No lo superará en la vida". De forma complementaria, informan sobre la existencia de avisadores para evitar este tipo de "tragedias" que se producen "cada vez con más frecuencia”, colocando en pantalla el siguiente rótulo informativo: TRAGEDIA BEBÉ OLVIDADA. ¿Cómo son las aplicaciones para evitar olvidarse a los niños en el coche? En la tertulia, Abad insiste que "no existió dolo por parte del padre, sino que todo se debió a un olvido".

\section{CONCLUSIONES}

\subsection{Número total de noticias/contenidos informativos}

Del total de los 111 contenidos informativos difundidos por los tres programas durante los días analizados, un total de 26 están dedicados a las noticias de sucesos $(23,63 \%)$ y 17 a tribunales/sucesos (15,45\%), lo que supone que cerca del $39 \%$ de los contenidos se centran en esta temática. Por programas, es La Mañana el que ofrece más noticias sobre sucesos y tribunales/sucesos, ocupando el mayor protagonismo en el conjunto de sus contenidos informativos (representatividad del 58,82 \%). A continuación, le sigue Espejo Público (30 \%) y en tercer lugar El Programa de Ana Rosa (un 29,79\%).

Tienen, por tanto, gran relevancia los sucesos en el magacín de la cadena pública, ya que como hemos visto casi el $60 \%$ de su programación está enfocada a esta temática, aunque también se tratan tribunales y otras noticias de carácter social, cultural, de entretenimiento y de autopromoción de TVE como, por ejemplo, de "Operación Triunfo". Los contenidos informativos de los dos programas de cadenas privadas emiten, en las primeras horas, noticias sobre política y, posteriormente, dan paso a otros más populares como sucesos, tribunales o corazón. 
Gráfico 1

Total de contenidos informativos en conjunto y por programas

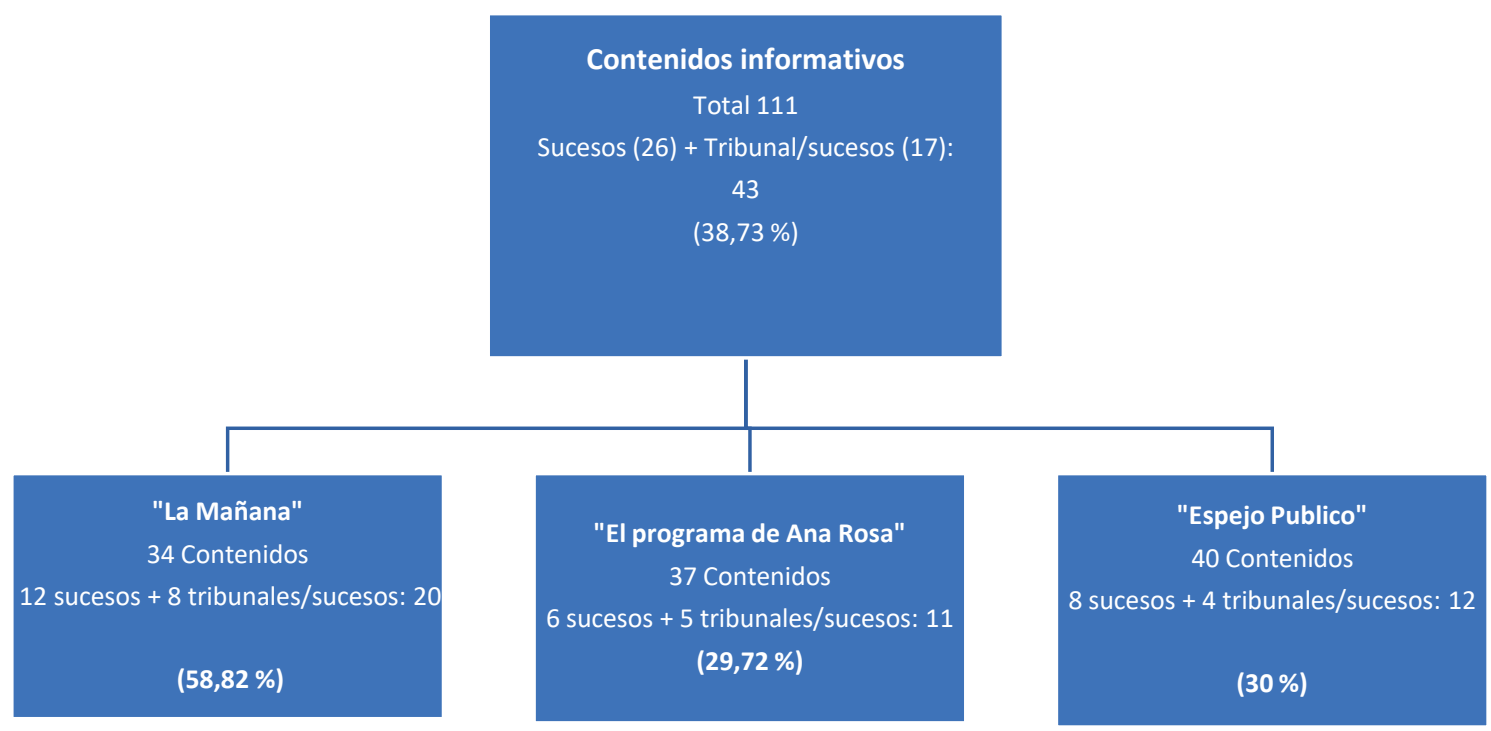

Fuente: elaboración propia.

\subsection{Temática}

En los tres programas analizados todas las noticias de sucesos son de temática delictiva. En cuanto a tribunales, los tres programas se centran casi exclusivamente en sucesos, excepto en Espejo Público que del total de sus cinco informaciones judiciales una es de política. La Mañana es el que más noticias emite sobre tribunales y a la par se encuentran los otros dos matinales.

A diferencia de los dos programas competidores, el de TVE tiene menor duración (dos horas), ya que el contenido de actualidad política y debate se emite previamente en Los desayunos de TVE (08:30-10:00 h.) y posteriormente en Más desayunos (12:00-13:30 h.). Por tanto, se trata de un magacín mucho más centrado en noticias de sucesos y sociedad. En los otros dos programas la temática política ocupa un espacio destacado, sobre todo en las primeras horas, con entrevistas en directo a políticos y el posterior debate con los tertulianos.

Los tres programas coinciden en emitir el tiroteo de Estepona (y posterior hallazgo del cadáver del hombre secuestrado) y la muerte de una bebé olvidada por su padre en el coche, los días 3 y 4 respectivamente, temas que son cubiertos en directo por reporteros enviados al lugar de los hechos. El tema de la agresión a un maestro en Sagunto y la detención del autor lo emiten también los tres magacines el 4 de octubre, haciendo la salvedad de que La Mañana ya había informado sobre este suceso el día anterior y los otros no. Son los tres sucesos de mayor proyección mediática. El suceso del desalojo del poblado chabolista de Son Banya (Palma) del día 3 es repetido tanto en La Mañana como en Espejo Público.

Luego cada programa emite otros sucesos diferenciados del resto, siendo más numerosos los ofrecidos por TVE (abusos sexuales y laborales en Huelva, insultos de dos cantantes a una concejal, muertes en Coín, fallecimiento de un recién nacido por ataque de un perro, mafias de inmigrantes en Melilla, acoso escolar en España y asesinatos por violencia machista; éstos últimos son propios y enfocados como de servicio público), Antena 3 (caso de un crimen no resuelto, acontecido en 2017 y tratado como información de servicio público; incautación de 
un millón de euros en El Prat y el traslado de cárcel de las autoras del 'Crimen Isabel Carrasco') y Tele 5 (casos sobre los homicidios de la 'Viuda negra de Alicante' y del 'Parricida del acantilado'). Como comprobamos, en las cadenas privadas la temática de crímenes adquiere mayor protagonismo.

\subsection{Titulares/Rótulos}

En los tres programas se combinan los títulos informativos con los interpretativos y, modo de antetítulo, se incide especialmente en que los televidentes vean que se trata de noticias de última hora, donde prima la actualidad. Los titulares principales van en mayúsculas, a mayor tamaño y en un color diferente a los subtítulos que figuran debajo de aquéllos y que durante el desarrollo de las noticias van cambiando por otros de última hora. Según los titulares analizados, los de La Mañana son, en general, más informativos y los de Espejo Público y El Programa de AR más interpretativos, cinematográficos, llamativos e impactantes, incurriendo en ocasiones en el sensacionalismo.

En cuanto al formato, los titulares se visualizan en la pantalla a modo de rótulos informativos, los cuales van cambiando en función del desarrollo de los hechos y suelen estar encabezados por 'Ultima hora', 'Directo', 'Exclusiva', 'Conexión redacción', junto a la mosca o logo identificativo de cada programa. También es frecuente el recurso de faldones en la parte inferior de la pantalla, cuando se anuncia otra próxima noticia que se emitirá inmediatamente, encabezada por 'A continuación'. En los tres programas se utiliza la técnica de la ventana (máscara gráfica), donde las presentadoras contactan en directo con los reporteros y aparecen en pantalla -a modo de recuadro- las imágenes de los dos a la vez con los rótulos destacados.

\subsection{Fuentes}

En los tres programas prevalecen las fuentes no oficiales $(61,11 \%)$ frente a las oficiales $(16,66$ $\%$ ). En cuanto a las fuentes indeterminadas (no constan/no se citan o se atribuyen de forma indefinida, bajo la expresión "según fuentes de la investigación..." o "según fuentes del caso...", que suelen proceder del ámbito policial) tienen una representatividad del 14,44 \%.

Las fuentes no oficiales más utilizadas son las vecinales, los testigos, los amigos o allegados y las propias víctimas, seguidas por las provenientes de otros medios de comunicación (se observa que estos programas se informan a través de la prensa local, que es la que hace un tratamiento más amplio y periodístico de los sucesos) y en menor número del autor o autora del suceso. Las fuentes oficiales proceden mayoritariamente de la Policía Nacional o Guardia Civil y en menor medida son judiciales o de organismos institucionales.

La mayoría de las noticias de sucesos que son cubiertas por los reporteros en el lugar de los hechos, emplean fuentes directas (declaraciones de las víctimas cuando es posible, personas afectadas, los testigos y vecinos), complementadas con las imágenes tomadas por las respectivas cadenas (son una buena fuente informativa, permitiendo situar a los telespectadores en el lugar de los hechos e incluso en ocasiones que vean lo que está pasando en el mismo momento en que ocurren los sucesos, como es el caso del desalojo chabolista ya citado). Son imágenes mayoritariamente en directo, aunque también utilizan imágenes de archivo propias o facilitadas por otras fuentes ajenas a las tres cadenas.

En el resto de sucesos no cubiertos por reporteros de calle son las presentadoras las que entrevistan en directo en el plató o telefónicamente a las víctimas o a los protagonistas de los 
sucesos. Si se trata de sucesos sobre crímenes, se acude a testigos, familiares, amigos o compañeros de los asesinados e incluso a los presuntos autores del delito.

Estas informaciones son posteriormente valoradas e interpretadas en las tertulias. Algunos tertulianos son también una fuente informativa, al aportar novedades en los casos que se debaten, sobre todo las aportaciones de los periodistas de sucesos y de expertos policiales y criminólogos que suelen facilitar datos que han recabado de sus contactos. El resto de los integrantes de las tertulias (periodistas generalistas, psicólogos o abogados) se limitan a dar sus opiniones, conjeturas o suposiciones, de carácter personal y genérico, sin entrar en el fondo de la cuestión.

Como hemos comentado, los tres programas cuentan con especialistas que realizan análisis más rigurosos y contrastados sobre los hechos, pero también tertulianos generalistas que no conocen la materia y ofrecen sus impresiones al respecto, ya que son colaboradores que dan sus opiniones sobre temas diversos y no sólo de sucesos.

Con respecto al análisis de cada programa, La Mañana es el que computa el mayor número de fuentes empleadas (un total de 35), seguido de Espejo Público (28) y AR (27). En cuanto al tipo de fuentes, es el magacín de TVE el que con mayor frecuencia $(11,11 \%)$ cita las fuentes oficiales frente a los dos programas de las cadenas privadas que tienden más hacia las fuentes no oficiales. Tiene todo el sentido, teniendo en cuenta que la cadena pública ofrece algunos reportajes de servicio público y acude a fuentes institucionales. Destaca especialmente El programa de Ana Rosa, que es el que en conjunto tiene una representatividad más elevada en el empleo de fuentes no oficiales $(26,66 \%)$, siendo las vecinales las más citadas. También hay que mencionar el hecho de que La Mañana sea el matinal que con más frecuencia emplea las fuentes indeterminadas. Por los datos extraídos de Espejo Público, se pone de manifiesto que es el programa con un empleo algo más equilibrado entre los tres tipos de fuentes, aunque prevalezcan las no oficiales.

Tabla 1

Variable 'Fuentes'

Oficiales

\begin{tabular}{|l|c|c|c|c|}
\hline La Mañana & 10 & 16 & $\mathbf{9}$ & 35 \\
\hline El programa de AR & 1 & 24 & 2 & 27 \\
\hline Espejo Público & 4 & 15 & 2 & 90 \\
\hline Total porcentual & $15(16,66 \%)$ & $55(61,11 \%)$ & $13(14,44 \%)$ & 28 \\
\hline
\end{tabular}

Fuente: elaboración propia.

\subsection{Géneros}

Se alternan los géneros periodísticos informativos (noticia y reportaje de calle), complementados con los de opinión e interpretación (gran protagonismo del formato televisivo de las tertulias para el análisis, debate y comentario) y la entrevista como recurso imprescindible tanto en el plató como en la calle. La noticia es el género con mayor frecuencia de uso en las informaciones de sucesos, seguida del reportaje de calle en directo que suele ir acompañado de entrevistas a los afectados, los testigos de los hechos o los vecinos. Además, se utiliza la noticia como entradilla informativa en el plató y el posterior desarrollo de los hechos informativos con la narración de los reporteros en el lugar de los hechos. La entrevista 
en directo, dentro del plató, es un recurso más empleado en las cadenas privadas -como anuncio de una exclusiva que se realiza al protagonista del suceso- que en la pública.

La tertulia, como formato televisivo, se convierte en un género propio (género opinativo), ocupando una parte importante del espacio dedicado a los sucesos y otros contenidos, especialmente en las cadenas privadas. Las tertulias son un recurso imprescindible para llenar grandes espacios de tiempo en este tipo de programas de actualidad y entretenimiento, combinado desproporcionadamente la información con la excesiva opinión y los anodinos comentarios de los colaboradores no especializados.

\subsection{Tiempo}

De los tres programas analizados es La Mañana el que más minutos de emisión dedica a los sucesos y tribunales/sucesos, seguido por Espejo Público y en tercer lugar El Programa de Ana Rosa. En La Mañana el tiempo de sucesos y tribunales/sucesos ocupa más de la mitad del programa (supera la hora por día visionado), lo que pone de manifiesto la importante representatividad de este contenido (tal y como se muestran en las tablas 2 y 3 ) en el magacín de TVE. En conjunto es el contenido de sucesos el que tiene mayor espacio televisivo en $L a$ Mañana. Las informaciones de sucesos de más duración son dos temas propios elaborados por este programa, enfocados como reportajes de servicio público, como son el del acoso escolar y la violencia de género en España.

Tabla 2

Tiempo emisión La Mañana. Día 3 de octubre

\begin{tabular}{|l|c|c|c|}
\hline Duración total & Sucesos & Tribunales/Sucesos & Total Sucesos+Tribunales/Sucesos \\
\hline $\begin{array}{l}105^{\prime}(1 \text { hora y } 45 \\
\text { minutos) }\end{array}$ & $44^{\prime}(42,30 \%)$ & $21^{\prime}(20,19 \%)$ & $65^{\prime}$ (1 hora y 5 minutos) / (62,5 \%) \\
\hline
\end{tabular}

Fuente: elaboración propia.

Tabla 3

Tiempo emisión La Mañana. Día 4 de octubre

\begin{tabular}{|c|c|c|c|}
\hline Duración total & Sucesos & Tribunales/Sucesos & Total Sucesos+Tribunales/Sucesos \\
\hline $\begin{array}{l}102^{\prime} \text { (1 hora y } 42 \\
\text { minutos) }\end{array}$ & $35^{\prime}(34,31 \%)$ & $26^{\prime}(25,49 \%)$ & $61^{\prime}$ (1 hora y 1 minuto) / (59,80 \%) \\
\hline
\end{tabular}

Fuente: elaboración propia.

En El Programa de Ana Rosa el tiempo que ocupan sucesos y tribunales/sucesos en el conjunto de contenidos tiene una representatividad que oscila entre el $17 \%$ y el $18 \%$ por programa emitido (ver tablas 4 y 5). Por tanto, significativamente más baja que en La Mañana de TVE. Los contenidos de 'Corazón' y 'Política' son a los que se le dedican más tiempo, seguido en tercer lugar por sucesos y tribunales/sucesos. Las informaciones de sucesos que ocupan más minutos son el caso del 'Parricida de Sabadell' (tema propio elaborado por este programa) y la noticia del tiroteo de Estepona y posterior hallazgo en Cádiz del cadáver del hombre secuestrado (Tele5 le hace un seguimiento más amplio a este suceso al ponerlo en relación con 
el narcotráfico en la Costa del Sol). Como se observa en las tablas, los sucesos propiamente dichos tienen un tratamiento televisivo mayor que el de tribunales/sucesos.

Tabla 4

Tiempo emisión El Programa de AR. Día 3 de octubre

\begin{tabular}{|l|c|c|c|}
\hline Duración total & Sucesos & Tribunales/Sucesos & Total Sucesos+Tribunales/Sucesos \\
\hline $\begin{array}{l}222^{\prime}(3 \text { horas y } 42 \\
\text { minutos) }\end{array}$ & $31^{\prime}(14 \%)$ & $7^{\prime}(3 \%)$ & $38^{\prime}(17 \%)$ \\
\hline
\end{tabular}

Fuente: elaboración propia.

Tabla 5

Tiempo emisión El Programa de AR. Día 4 de octubre

\begin{tabular}{|l|c|c|c|}
\hline $\begin{array}{l}\text { Duración total } \\
\text { visionado }\end{array}$ & Sucesos & Tribunales/Sucesos & Total Sucesos+Tribunales/Sucesos \\
\hline $\begin{array}{l}222^{\prime}(3 \text { horas y } 42 \\
\text { minutos) }\end{array}$ & $29^{\prime}(13,06 \%)$ & $11^{\prime}(4,95 \%)$ & $40^{\prime}(18 \%)$ \\
\hline
\end{tabular}

Fuente: elaboración propia.

En Espejo Público el tiempo que ocupan sucesos y tribunales/sucesos en el conjunto de contenidos tiene una representatividad que oscila entre el $19,19 \%$ y el $23,66 \%$ por programa visionado (ver tablas 6 y 7). De los dos programas de cadenas televisivas privadas, es el de Antena 3 el que más minutos dedica a esta temática. Los contenidos políticos son los que gozan de más tiempo televisivo, seguido de sucesos y tribunales/sucesos. En cuanto a las informaciones de sucesos a las que se les dedican más minutos de emisión, son las referidas al desalojo policial del poblado de Son Banya y la tragedia de la bebé muerta en un coche por olvido de su padre.

Tabla 6

Tiempo emisión Espejo Público. Día 3 de octubre

\begin{tabular}{|l|c|c|c|}
\hline Duración total & Sucesos & Tribunales/Sucesos & Total Sucesos+Tribunales/Sucesos \\
\hline $\begin{array}{l}224^{\prime}(3 \text { horas y } 44 \\
\text { minutos) }\end{array}$ & $28^{\prime}(12,5 \%)$ & $1^{\prime}(6,69 \%)$ & $43^{\prime}(19,19 \%)$ \\
\hline
\end{tabular}

Fuente: elaboración propia.

Tabla 7

Tiempo emisión Espejo Público. Día 4 de octubre

\begin{tabular}{|l|c|c|c|}
\hline Duración total & Sucesos & Tribunales/Sucesos & Total Sucesos+Tribunales/Sucesos \\
\hline $\begin{array}{l}224^{\prime}(3 \text { horas y } 44 \\
\text { minutos) }\end{array}$ & $20^{\prime}(8,92 \%)$ & $33^{\prime}(14,73 \%)$ & $53^{\prime}(23,66 \%)$ \\
\hline
\end{tabular}

Fuente: elaboración propia.

\subsection{Tratamiento}

Cada uno de los programas analizados tienen tratamientos diferenciados que marcan sus estilos informativos, aunque el esquema de formato televisivo sea muy similar. La dinámica de 
inicio de estos magacines es la siguiente: anuncian noticias de portada y se conecta con los reporteros en el lugar de los hechos con imágenes en directo $y$, posteriormente, se vuelve a comunicar con ellos para que cuenten los detalles. De fondo, cuando hay sucesos, se emite una música ambiental dinámica, de suspense, acompañando a los enunciados. El recurso de la música instrumental a veces tiende a favorecer el sensacionalismo de la información de sucesos que se está emitiendo -más evidente en las cadenas privadas-, al provocar en el televidente una mayor sensibilidad y afectación tras un hilo musical de tragedia y alarma. Es una técnica cinematográfica aplicada en los platós de televisión que sirve en ocasiones para manipular las emociones de los telespectadores.

Los tres programas complementan la actualidad informativa con la tertulia donde colaboradores y expertos interpretan y valoran los sucesos que han acontecido. Las tertulias son un buen recurso para llenar grandes espacios de tiempo en estos magacines. Generalmente los colaboradores son de dos tipos: expertos/especialistas en sucesos (criminólogos, policías o periodistas especializados en esta temática que sí aportan datos de interés a los casos que se debaten y suponen un añadido de calidad al programa) y generalistas (periodistas, psicólogos o abogados que opinan de todo de forma genérica y se limitan a dar sus opiniones o interpretaciones, sin aportar informaciones útiles o novedosas).

En cuanto al tratamiento de las noticias es, por una parte, informativo, de periodismo a pie de calle, pero como hemos comprobado en conjunto los tres programas dedican más tiempo a la interpretación y valoración de los hechos que a la noticia en sí. La Mañana es el programa que muestra una distribución más equilibrada entre información y opinión. El programa de Mediaset es el que realiza un tratamiento más sensacionalista y La Mañana es el más informativo. El Programa de AR emite dos sucesos, enfocados como exclusivas, los cuales no son propiamente noticias, como son los casos 'Viuda Negra' y 'Parricida del acantilado', de corte sensacionalista e incluso diríamos amarillista especialmente el primero. Espejo Público ofrece varios sucesos distintos al de los difundidos por los de la competencia, como son un crimen acontecido en 2017 -tratado como un caso no resuelto y de servicio público-, una noticia de última hora sobre blanqueo de capitales y el traslado de las presas del caso 'Crimen Isabel Carrasco'. Es de observar que las informaciones propias de TVE se enfocan como de servicio público, a diferencia de los programas de los canales privados, que tienen la tendencia a publicitar algunos de sus contenidos diferenciados como exclusivas, que como hemos comprobado en ocasiones no son tales.

Las imágenes son fundamentales, pero especialmente en televisión. En el ámbito de los sucesos, las imágenes nos muestran en ocasiones los rostros de las víctimas y de los autores y sobre todo el escenario del delito, del siniestro y del crimen o su entorno más próximo. Tienen gran relevancia, dan a conocer la ubicación donde se ha cometido el delito o enseñan las vistas exteriores y los alrededores del suceso junto a policías, vecinos, cámaras de televisión y fotógrafos. Sirven para documentar gráficamente las primeras noticias que se difunden después de estos sucesos. En los programas analizados cuando no existen imágenes en directo, se ofrecen imágenes de archivo, fotomontajes, fotografías, imágenes y vídeos de redes sociales, etcétera. Ahora bien, el recurso de los montajes fotográficos puede degenerar en el sensacionalismo y amarillismo porque no aportan información relevante, sólo sirven como pantalla de espectáculo, como circo mediático, como vimos en el caso de El Programa de AR del 4 de octubre de 2018 con el caso 'Viuda negra de Alicante'. 
En cuanto al formato audiovisual, los tres programas coinciden en el siguiente esquema: la presentadora va dando paso en directo a los reporteros desplazados en el lugar de los hechos para que les diga "la primera hora". Los periodistas informan sobre los sucesos mientras se les enfoca en primer plano y de fondo las imágenes de los escenarios y posteriormente se comentan las noticias en la tertulia. En estos magacines televisivos las presentadoras (son las tres periodistas) anuncian en el estudio los principales temas de portada, ofreciendo la imagen de la primera noticia (entradilla+vídeo), conexión en directo con los reporteros de calle y la tertulia. Tienen gran importancia en estos programas las conexiones en directo para resaltar la actualidad de última hora. Se ofrecen primeros planos de las presentadoras y de los reporteros de la calle, general en las tertulias, así como medio o general en los escenarios de los hechos.

\section{Referencias}

Antena3 Noticias (2021, 2 de septiembre). Espejo Público estrena temporada con el regreso de Susanna Griso. https://bit.ly/3ajgXQB

Antena3 (2016, 10 de mayo). Presentadora de Espejo Público / Susana Griso. https://bit.ly/3AnyNMQ

Atresmedia (2012, 28 de diciembre). Código de Conducta. https://bit.ly/3BpwESi

Consejo Audiovisual de Andalucía (2015). Informe sobre el tratamiento informativo dado por las televisiones a un caso de violencia de género en Sanlúcar la Mayor (Sevilla). https://bit.ly/3AhMNry

Fadón-Reguilón, C. (2017). Información sobre personas desaparecidas en los magazines matinales televisivos. El caso Diana Quer en La Mañana de TVE y el Programa de Ana Rosa de Telecinco. Tesis de Grado, Universidad de Valladolid, Valladolid, España. https://bit.ly/3v6aodX

FormulaTV (2020, 20 de octubre). Espejo Público. https://bit.ly/3AzfWid

Molina, B. (2021, 15 de julio). La productora de Ana Rosa ficha a un mítico periodista de espejo Público. El Confidencial. https://bit.ly/3iHAUFw

RTVE (2018, 5 de septiembre). La mañana. https://bit.ly/3Ap1HML

Telecinco (2018, 7 de septiembre). El programa de Ana Rosa inicia temporada con 16 nuevas colaboraciones y entrevistas a los principales líderes políticos. https://bit.ly/3illCjF

\section{Semblanza de la autora}

Rosa Rodríguez Cárcela es periodista, doctora en Comunicación y licenciada en Derecho. Es miembro del Grupo de Investigación en Estructura, Historia y Contenidos de la Comunicación de la Universidad de Sevilla. Especializada en periodismo de sucesos, ha publicado trabajos de investigación sobre esta especialidad informativa en revistas científicas, junto a capítulos en diversos libros. Es autora del Manual de Periodismo de Sucesos (2015). Ha impartido clases, colaborado en diversos periódicos locales y actualmente colabora en El Correo de Andalucía. 